\title{
Holocene hydrography evolution in the Alboran Sea: a multi-record and multi-proxy comparison
}

\author{
Albert Català ${ }^{1}$, Isabel Cacho ${ }^{1}$, Jaime Frigola ${ }^{1}$, Leopoldo D. Pena ${ }^{1}$, and Fabrizio Lirer ${ }^{2}$ \\ ${ }^{1}$ Grup de Recerca Consolidat en Geociències Marines, Departament de Dinàmica de la Terra i de l'Oceà, \\ Universitat de Barcelona (UB), Barcelona, Spain \\ ${ }^{2}$ Istituto di Scienze Marine (ISMAR)-CNR, Sede di Napoli, Naples, Italy
}

Correspondence: Albert Català (al_catala@ub.edu)

Received: 26 November 2018 - Discussion started: 29 November 2018

Accepted: 26 April 2019 - Published: 23 May 2019

\begin{abstract}
A new high-resolution deglacial and Holocene sea surface temperature (SST) reconstruction is presented for the Alboran Sea (western Mediterranean), based on $\mathrm{Mg} / \mathrm{Ca}$ ratios measured in the planktonic foraminifera Globigerina bulloides. This new record is evaluated by comparison with other $\mathrm{Mg} / \mathrm{Ca} \mathrm{SST}$ records and previously published alkenone SST reconstructions from the same region for both the Holocene and glacial periods. In all cases there is a high degree of coherence between the different $\mathrm{Mg} / \mathrm{Ca}$ SST records but strong discrepancies when compared to the alkenone SST records. We argue that these discrepancies are due to differences in the proxy response during deglaciation which we hypothesize to reflect a resilience strategy of $G$. bulloides, changing its main growth season, and consequently $\mathrm{Mg} / \mathrm{Ca}$ records a shorter deglacial warming than alkenones. In contrast, short-term Holocene SST variability is larger in the $\mathrm{Mg} / \mathrm{Ca}$ SST than in the alkenone SST records. We propose that the larger $\mathrm{Mg} / \mathrm{Ca} \mathrm{SST}$ variability is a result of spring temperatures variability, while the smoothed alkenone SST variability represents averaged annual temperatures. The $\mathrm{Mg} / \mathrm{Ca} \mathrm{SST}$ record differentiates the Holocene into three periods: (1) the warmest SST values occurred during the Early Holocene (11.7-9 cal. kyr BP), (2) a continuous cooling trend occurred during the Middle Holocene that culminated in the coldest Holocene SST having a double cold peak structure centred at around 4.2 cal. kyr BP, and (3) the Late Holocene (4.2 cal. kyr BP to present) did not follow any clear cooling/warming trend although millennial-scale oscillations were enhanced. This SST evolution is discussed in the context of the changing properties in the Atlantic inflow water associated with North Atlantic circulation conditions and
\end{abstract}

also with local hydrographical and atmospheric changes. We propose that a tight link between North Atlantic circulation patterns and the inflow of surface waters into the Mediterranean played a major role in controlling Holocene climatic variability of this region.

\section{Introduction}

Overall, Holocene climate evolution ( 11.7 cal. kyr BP to present) is considered more stable than during the previous glacial period (115-17.7 cal. kyr BP; Bond et al., 1997; Cacho et al., 1999; Martrat et al., 2014). However, there is an increasing number of worldwide distributed Holocene climate records that reveal significant changes in both the longterm patterns pathed by orbital forcing (e.g. Marchal et al., 2002; Lorenz and Lohmann, 2004; Tzedakis, 2007; Wanner et al., 2008; Tinner et al., 2009; Bartlein et al., 2011) and millennial- and centennial-scale variability (e.g. Bond et al., 1997, 2001; Andrews et al., 2003; Marchitto and deMenocal, 2003; Moros et al., 2004; Debret et al., 2007, 2009; Thornalley et al., 2009; Giraudeau et al., 2010; NietoMoreno et al., 2011). In an oceanic context, and particularly for the North Atlantic, there is solid evidence for Holocene changes in several oceanographic parameters linked to Atlantic Meridional Overturning Circulation (AMOC), such as heat exchange within the subpolar gyre (SPG) and the subtropical gyre (STG) (Bond et al., 1997, 2001; Thornalley et al., 2009; Colin et al., 2010; Repschläger et al., 2017; Jalali et al., 2019). Studies on Holocene atmospheric conditions over the North Atlantic region suggest the occurrence of north- 
ward and southward displacements of the winter storm tracks (Fletcher et al., 2012; Desprat et al., 2013; Chabaud et al., 2014; Zielhofer et al., 2017). The western Mediterranean Sea is very sensitive to changes in Atlantic Ocean conditions. These oceanic and atmospheric connections have been welldocumented and described for the last glacial period (Cacho et al., 1999; Moreno et al., 2002; Sierro et al., 2005; Frigola et al., 2008; Toucane et al., 2012) when intense millennial-scale variability occurred that was associated with major changes in the AMOC (the so-called Dansgaard-Oeschger cycles and Heinrich events). However, even though the Holocene climate variability over the western Mediterranean has also been extensively studied (i.e. Cacho et al., 2001; Frigola et al., 2007; Rodrigo-Gámiz et al., 2011; Ausin et al., 2015; Jalali et al., 2016), unlike the glacial periods, potential connections to the changes that occurred in the North Atlantic Ocean still remain unclear.

One of the limitations in the study of Holocene climate variability is the sensitivity of the climate proxies. During this period, the natural range of variability for sea surface temperature (SST) or $\delta^{18} \mathrm{O}_{\mathrm{sw}}$ is relatively small, and these natural changes are often below the magnitude of the proxy sensitivity. For this reason, to validate the climate value of the proxy signals for the Holocene, it is critical to reproduce them in comparable records and ideally with independent proxies. With this goal, here we present a new highresolution Holocene SST record based on the $\mathrm{Mg} / \mathrm{Ca}$ ratio in the planktonic foraminifera $G$. bulloides from core ALB-2 of the Alboran Sea. This record is also compared with three other $\mathrm{Mg} / \mathrm{Ca}$ ratios for $\mathrm{G}$. bulloides derived SST records from the western Mediterranean, two new ones (MD95-2043 and MD99-2343), and another that was previously published (ODP 976; Jiménez-Amat and Zahn, 2015). The western Mediterranean Sea has been intensively studied and several SST records exist, mostly based on the application of the UK'37 index measured on alkenones (Cacho et al., 2001; Martrat et al., 2004; Rodrigo-Gámiz et al., 2014; Ausin et al., 2015). This multicore and multi-proxy approach comparison enables a discussion of the proxy limitations in order to identify some SST changes which have discrepancies between the two considered proxies. The new high-resolution $\mathrm{Mg} / \mathrm{Ca}$ SST record allows us to discuss the Holocene SST evolution in this region and to hypothesize potential links with changes in the North Atlantic circulation.

\section{Regional settings}

Climate in the western Mediterranean is characterized by warm and dry summers, while autumn and winter are mild and humid. During winters, westerly winds are displaced southward, thus causing storms to create more humid conditions over the western Mediterranean (Trigo et al., 2002; Combourieu Nebout et al., 2009; Fletcher et al., 2012; Roberts et al., 2012; Nieto-Moreno et al., 2011). At the end of summer and in early autumn the temperature differences between the air masses and the surface Mediterranean can produce violent precipitation events (Lionello et al., 2006; Sabatier et al., 2012).

Alboran Sea oceanography (Fig. 1a and b) is controlled by the exchange of water masses between the Mediterranean and the Atlantic Ocean. The low-salinity Atlantic waters enter the Mediterranean Sea as a surface layer while high-salinity waters from the Mediterranean outflow into the Atlantic Ocean as an intermediate water mass (Mediterranean Outflow Water, MOW). Surface waters at the Alboran Sea are typically defined as Modified Atlantic Water (MAW), composed mainly of a mixing of Surface Atlantic Water (SAW) and the Eastern North Atlantic Central Water (ENACW) (Bray et al., 1995; Millot, 2009) (Fig. 1a and b). This ENACW has been characterized as waters from two different source areas converging in the northwest of the Iberian Peninsula. One source has a subpolar origin (ENACWsp), which is formed near $46^{\circ} \mathrm{N}$ around the Celtic Sea (McCarteney and Talley, 1982). The other source has a subtropical origin (ENACWst) formed near $35^{\circ} \mathrm{N}$ around the Azores islands (Fiúza, 1984) (Fig. 1a). Hydrographic properties of these water masses are related to changes in heat and salt transport through the STG-SPG that ultimately modulate the AMOC (i.e. Cléroux et al., 2012; Thornalley et al., 2009; Gao and Yu, 2008; Böning et al., 2006). The MAW inflow describes two anticyclonic gyres in the Alboran Sea (western and eastern Alboran gyres, WAG and EAG), which change its properties as the inflow water progresses eastward (Fig. 1b). Deeper in the water column of the Alboran Sea, the Levantine Intermediate Water (LIW) occurs at 220-600 mwd (metres water depth) and the Western Mediterranean Deep Water (WMDW), under $600 \mathrm{mwd}$. The ALB-2 core is located in the centre of the WAG. Sediment fluxes based on sediment traps from the same location show relatively high values attributed to a funnelling effect by the gyre, thus capturing particles from the edges and moving them towards the centre (Fabres et al., 2002).

\section{Materials and methods}

Core HER-GC-ALB-2 (here abbreviated as ALB-2) was retrieved from the Alboran Sea $\left(36^{\circ} 0^{\prime} 44.80^{\prime \prime} \mathrm{N}\right.$, $4^{\circ} 16^{\prime} 24.38^{\prime \prime} \mathrm{W} ; 1313 \mathrm{~m}$ ) during the HERMESIONE cruise in 2009 (Fig. 1b), on board B/O Hespérides. Core ALB-2 was recovered with a gravity core system and covers a continuous sequence of $337 \mathrm{~m}$ length. Information on the other sediment cores included in the discussion appears in Table S1 of Supplement.

Geochemical analyses were performed on planktonic foraminifera $G$. bulloides sampled every $1 \mathrm{~cm}$. The individual specimens were hand-picked between 250 and $355 \mu \mathrm{m}$ size fractions in order to obtain a homogenous population. 


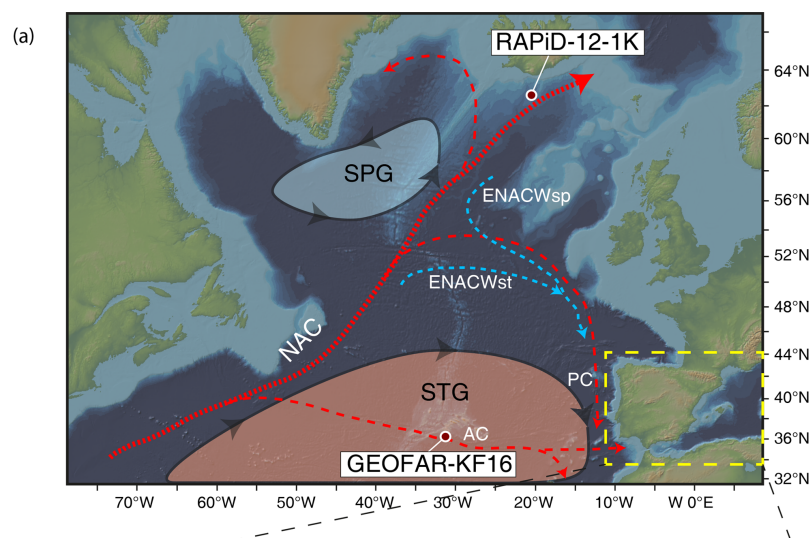

(b)

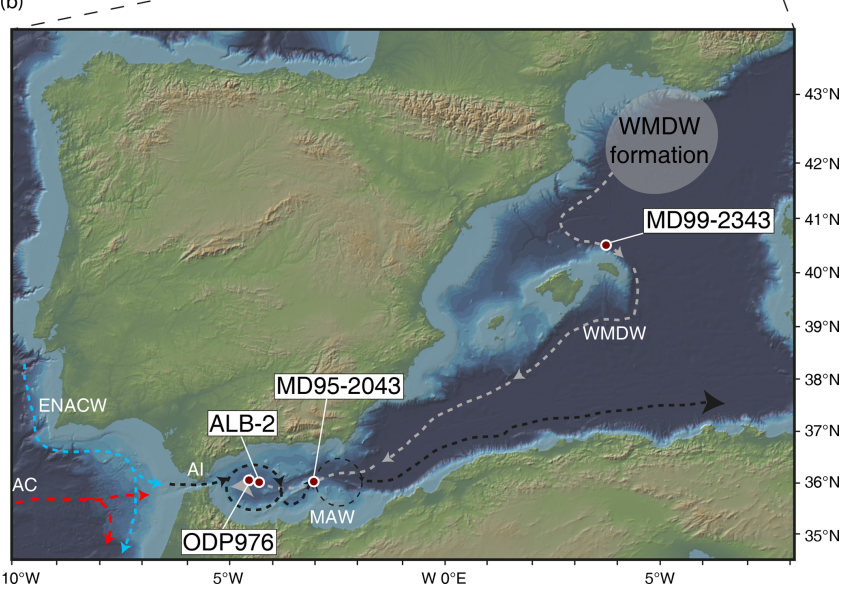

Figure 1. Schematic modern surface and central hydrography of the North Atlantic currents. Basic map obtained from Marine Geoscience Data System (C2008-2018 - all rights reserved. Warm surface currents are shown by dashed red arrows. (a) Central currents are shown by dashed light-blue arrows. (b) Oceanographic gyres are represented by red circles. Abbreviations are listed as follows: NAC, North Atlantic Current; AC, Azores Current; PC, Portugal Current; ENACWsp, East North Atlantic Central Water Subpolar; ENACWst, East North Atlantic Central Water Subtropical; SPG, Subpolar Gyre; STG, Subtropical Gyre; WMDW, Western Mediterranean Deep Water; AI, Atlantic inflow; MAW, Modified Atlantic Water. Red dots circled white indicate the core locations.

The selected specimens showed apparently well-preserved and clean shells.

\subsection{Stable isotopes}

Around 10 specimens of G. bulloides per sample were crushed between two glass slides under a binocular microscope in order to open the chambers and allow for cleaning of the shells' interiors. Samples were cleaned with $500 \mu \mathrm{L}$ of methanol in an ultrasonic bath for $30 \mathrm{~s}$ in order to mobilize the clay residues. The residual methanol was removed and samples were dried prior to analysis. The analyses were performed with an isotope-ratio mass spectrometer (IRMS), Finnigan-MAT 252, which was linked online to a single acid bath CarbonKiel-II carbonate preparation device at the Scientific and Technological Centre of the University of Barcelona (CCiT-UB). The analytical precision of laboratory standards for $\delta^{18} \mathrm{O}$ was better than $0.08 \%$. Calibration to Vienna Pee Dee Belemnite (VPDB) was carried out following NBS-19 standards (Coplen, 1996).

Seawater $\delta^{18} \mathrm{O}\left(\delta^{18} \mathrm{O}_{\mathrm{sw}}\right)$ was obtained after removing the temperature effect, using the Shackleton paleotemperature equation (Shackleton, 1974) on the G. bulloides $\delta^{18} \mathrm{O}$ signal using the G. bulloides $\mathrm{Mg} / \mathrm{Ca}$ SST values. The results are expressed in the SMOW (Standard Mean Ocean Water) water standard $\left(\delta^{18} \mathrm{O}_{\mathrm{sw}}\right)$ after the correction of Craig (1965).

\subsection{Chronologies}

The chronology of core ALB-2 is based on $14{ }^{14} \mathrm{C}$ AMS dates measured on planktonic foraminifera samples that were hand-picked from the $215-355 \mu \mathrm{m}$ fraction $(8-33 \mathrm{mg})$. The top 10 radiocarbon dates are based on monospecific samples of Globorotalia inflata, and the four older dates are based on multi-specific samples of planktonic foraminifera (Table S2). Radiocarbon ages were calibrated using MARINE13 calibration curves (Reimer et al., 2013). The age model was built using the Bayesian statistics software Bacon with the statistical package R (Blaaw and Christien, 2011) for marine sediments (Supplement Fig. S3). From the core top to the first ${ }^{14} \mathrm{C}$ AMS date $(10 \mathrm{~cm})$, the age model was calculated using a linear regression, assuming the age of the core top to be that of the sediment core recovery (2009 CE). The chronology at the base of the core was established using isotopic stratigraphy by correlating a well-expressed positive excursion in the $\delta^{18} \mathrm{O}-\mathrm{ALB}-2$ to a well-dated comparable structure in the $\delta^{18} \mathrm{O}-\mathrm{MD} 95-2043$ measured in both cases on G. bulloides (Table S2 and Fig. S3). According to the generated age model, the ALB- 2 core covers the last 15 cal. kyr BP with an average sedimentation rate of $22 \mathrm{~cm} \mathrm{kyr}^{-1}$, providing a time resolution of about 45 years for the applied sampling interval $(1 \mathrm{~cm})$.

The age model for MD99-2343 was improved from that originally published by Frigola et al. (2007), with nine new ${ }^{14} \mathrm{C}$ AMS dates incorporated into the previous age model (Table S4). The updated age model has $19{ }^{14} \mathrm{C}$ AMS dates covering the last $17 \mathrm{cal}$. kyr BP. This updated age model was also built using the Bayesian statistics software Bacon with the statistical package R (Blaaw and Christien, 2011) for marine sediments (Fig. S5). The upper $20 \mathrm{~cm}$ of this core was lost during its retrieval, but for chronological purposes the age of the missed core top was assumed to be the recovered year (1999 CE). The chronology during deglaciation was improved by adding two tie points, by correlating a marked $\delta^{18} \mathrm{O}$ structure in both the Minorca core MD99-2343 and the Alboran core MD95-2043 (Tables S4 and S5). 


\subsection{G. bulloides $\mathrm{Mg} / \mathrm{Ca}$ ratios and sea surface temperature estimates}

$\mathrm{Mg} / \mathrm{Ca}$ measurements in core ALB-2 were made on samples containing 50-60 specimens of G. bulloides, gently crushed between two glass slides under a binocular microscope, in order to open the chambers and allow the removal of contaminant phases from the shells' interiors. The cleaning protocol for the foraminifera shells was based on the full procedure described by Pena et al. (2005) which includes the reductive step. Once cleaned, each sample was dissolved in ultra-pure $1 \%$ nitric acid with $\mathrm{Rh}$ as an internal standard. After dissolution, samples were centrifuged to remove any potential undissolved mineral particles. Procedural blanks were routinely produced to detect any potential contamination problem during the sample cleaning and dissolution process.

Instrumental analyses were performed in an inductively coupled plasma mass spectrometer (ICP-MS), PerkinElmer Elan 6000, at CCiT-UB. Every four samples, a standard solution was analysed. The standard solution was prepared gravimetrically with known concentrations of $\mathrm{Mg}, \mathrm{Ca}, \mathrm{Mn}$, and $\mathrm{Al}$, and it was produced with a ratio (element/Ca) comparable to that expected for the samples. Analytical reproducibility obtained relative to the gravimetric standard samples was $1.62 \%(1 \sigma)$ for the $\mathrm{Mg} / \mathrm{Ca}$ ratio. Moreover, all $\mathrm{Mg} / \mathrm{Ca}$ ratios in this core were corrected using the same gravimetric standard for each ICP-MS round using a standard-sample bracketing (SSB) method, in order to correct the instrumental drift.

The G. bulloides $\mathrm{Mg} / \mathrm{Ca}$ ratios were then compared with other analysed ratios, i.e. $\mathrm{Al} / \mathrm{Ca}$ and $\mathrm{Mn} / \mathrm{Ca}$, in order to identify potential contamination by any remaining manganese oxides and/or aluminosilicates in the samples (Barker et al., 2003; Pena et al., 2005). Such potential contamination could provide anomalous high G. bulloides $\mathrm{Mg} / \mathrm{Ca}$ ratios and therefore overestimate the inferred SST values. In the ALB-2 record, Mn/Ca ratios above $2 \sigma\left(0.29 \mathrm{mmol} \mathrm{mol}^{-1}\right.$; over standard deviations of the average $\mathrm{Mn} / \mathrm{Ca}$ values) were removed (Fig. S6a). The $\mathrm{Al} / \mathrm{Ca}$ ratio was considered to potentially indicate the presence of unremoved silicates (likely clays), and those samples with values above $2 \sigma\left(1.74 \mathrm{mmol} \mathrm{mol}^{-1}\right)$ were also removed (Fig. S6b).

The G. bulloides $\mathrm{Mg} / \mathrm{Ca}$ records from cores MD95-2043 and MD99-2343 were produced following a comparable procedure to that described for the ALB-2 core, but, for these cores, the data to estimate analytical reproducibility and the $\mathrm{Mn} / \mathrm{Ca}$ and $\mathrm{Al} / \mathrm{Ca}$ ratios to evaluate the potential interference of contamination phases were not available. Consequently, the uncertainties associated with these complementary SST records are larger than those associated with the ALB-2 sediment core, which is the main focus of this study. G. bulloides $\mathrm{Mg} / \mathrm{Ca}$ ratios from core ODP 976, also included in the discussion, have already been published by JiménezAmat and Zahn (2015).

The G. bulloides $\mathrm{Mg} / \mathrm{Ca}$ ratios of the four discussed sediment cores have been converted to SST by applying the cali- bration from Cisneros et al. (2016). This calibration is based on G. bulloides $\mathrm{Mg} / \mathrm{Ca}$ ratios available from core top samples from the North Atlantic Ocean (Elderfield and Gansen, 2000) and the addition of core top samples from the western Mediterranean Sea. These Mediterranean samples extend the temperature range of the original calibration toward the warmer edge, and thus the obtained calibration better covers the oceanographic conditions of the western Mediterranean. This calibration provides realistic SST for the G. bulloides bloom season around April-May across the western Mediterranean (Cisneros et al., 2016). Since this calibration was performed on non-reductive cleaned samples, the $\mathrm{Mg} / \mathrm{Ca}$ ratios of those cores cleaned with the full reductive cleaning procedure were increased by $12 \%$ prior to the calibration application. This percentage accounts for the selective dissolution of high-Mg calcite that introduces this cleaning step (Barker et al., 2003; Rosenthal et al., 2004). However, it has been proposed that foraminifera $\mathrm{Mg} / \mathrm{Ca}$ ratios could be also affected by salinity, particularly in high-salinity environments such as the Mediterranean Sea, challenging its applicability as an SST proxy (Ferguson et al., 2008). But the sensitivity of $\mathrm{Mg} / \mathrm{Ca}$ ratios to high-salinity environments, according to culture experiments, appears to be far lower than that previously proposed in base-to-core top sediments (Hönisch et al., 2013). In addition, the anomalous high $\mathrm{Mg} / \mathrm{Ca}$ ratios detected in high-salinity environments such as the Mediterranean Sea and Red Sea have been attributed to high-Mg diagenetic overprints (Hoogakker et al., 2009; van Raden et al., 2011). In the case of the studied Mediterranean cores, the obtained ratios are coherent within the expected ranges of the calibration and appear not to be affected by secondary digenetic calcite.

\section{Results and discussion}

\subsection{Holocene evolution in western Mediterranean G. bulloides $-\delta^{18} \mathrm{O}$ records}

We now compare the new $\delta^{18} \mathrm{O}$ record from ALB-2 to other previously published high-resolution $\delta^{18} \mathrm{O}$ records from the western Mediterranean (Cacho et al., 1999; Frigola et al., 2007; Jiménez-Amat and Zahn, 2015) in order to evaluate the regional significance of the recorded signal (Fig. 2). The main patterns in the $\delta^{18} \mathrm{O}$ records show an extraordinary resemblance to each other, and even several centennialscale structures can be correlated through the cores, taking into account the individual core chronological uncertainties (Fig. 2c). The isotopic depletion associated with the last termination ends in all four records at around 9 cal. kyr BP. Throughout the Holocene, all the G. bulloides $\delta^{18} \mathrm{O}$ records are rather stable, with several short oscillations $(0.2 \% o-0.3 \% o)$ and a slight enrichment trend toward the Late Holocene (Fig. 2b). This comparison supports the regional value of the captured paleoceanographic signal and the robustness of the individual age models. 


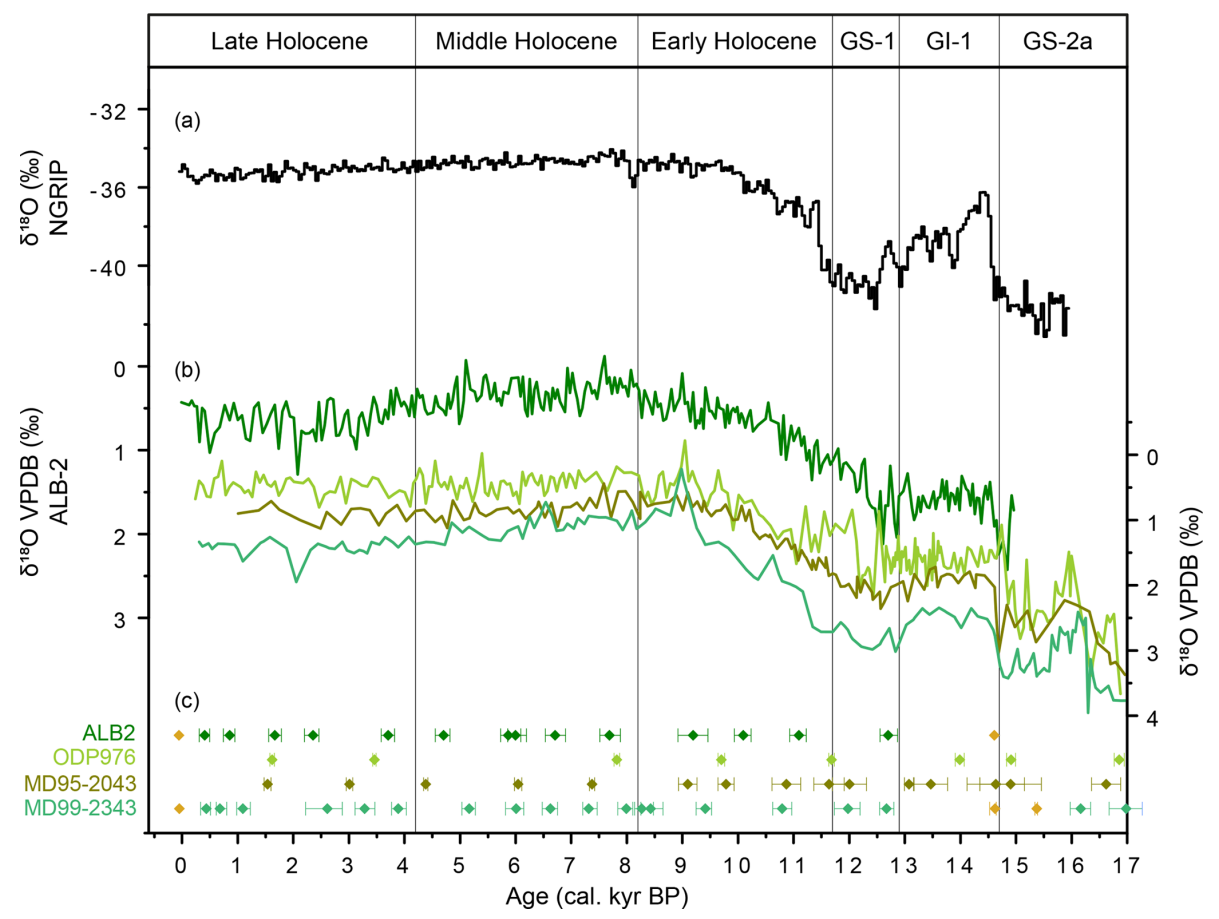

Figure 2. Comparison of $\delta^{18} \mathrm{O}$ (VPDB) records and their ${ }^{14} \mathrm{C}$ calibrated dates from the western Mediterranean Sea over the last 17 cal. kyr BP. (a) $\delta^{18} \mathrm{O} \%$ NGRIP record. (b) From the top to the base in green colour: ranges of $\delta^{18} \mathrm{O} \%$ (VPDB) records from the cores ALB-2, ODP976 (Combourieu-Nebot et al., 2002), MD95-2043 (Cacho et al., 1999), and MD99-2343 (Minorca drift). Note ALB-2 $\delta^{18}$ O \%o (VPDB) record is plotted with an independent $y$ axis from the others in order to help with figure compression. (c) ${ }^{14} \mathrm{C}$ calibrated dates with the available errors from each record shown above. Each date is coloured the same as the record, excluding the yellow dots, which represent tie points.

In terms of absolute values of the G. bulloides $\delta^{18} \mathrm{O}$ records, clear differences can be detected between the cores. Both the ALB-2 and ODP976 cores, located in the westernmost part of the Alboran Sea, display the lightest values (note that the curves in Fig. $2 \mathrm{~b}$ are plotted on independent $y$ axes). Core MD95-2043, located in the eastern part of the Alboran Sea, shows heavier $\delta^{18} \mathrm{O}$ values than the other two Alboran records (Fig. 2b). Finally, core MD99-2343, located north of the island of Minorca, shows the heaviest $\delta^{18} \mathrm{O}$ values. Such an isotopic pattern is consistent with the regional oceanography, showing the lightest $\delta^{18} \mathrm{O}$ values at those sites with a stronger influence of North Atlantic surface inflow, while the $\delta^{18} \mathrm{O}$ values become heavier along its path into the Mediterranean Sea. This situation reflects the excess of evaporation within the Mediterranean Sea that results in an enhancement of the salinity (Béthoux, 1980; Lacombe et al., 1981) but also of the marine water $\delta^{18} \mathrm{O}$ values. It is interesting to note that the presented isotopic records show a strong gradient between the western and eastern Alboran Sea (about 0.5\%o), probably due to strong surface mixing with the underlying Mediterranean waters driven by the two anticyclonic gyres (Tintore et al., 1988; Millot, 1999), supporting the argument that the Atlantic inflow became rapidly modified within the Alboran Sea. The isotopic change from the eastern Alboran Sea core (MD95-2043) and the Minorca core (MD99-2343) is even larger $(\sim 0.7 \%$ ), reflecting the long path of these inflowing Atlantic waters through the western Mediterranean before reaching Minorca.

\subsection{Sea surface temperatures: multi-record and multi-proxy comparison}

According to the ALB-2 Mg/Ca SST record, the Holocene maximum temperatures $\left(20.0 \pm 1.0^{\circ} \mathrm{C}\right.$; uncertainties of the average values represent $1 \sigma$; uncertainty values are those derived from the $\mathrm{Mg} / \mathrm{Ca} \mathrm{SST}$ calibration) were reached at the onset of the Holocene $\sim 11.0 \mathrm{kyr}$ (Fig. 3b); a general cooling trend until the present characterizes this record, punctuated by several short-term oscillations (maximum of $2^{\circ} \mathrm{C}$ ). However, the ALB-2 SST record can be divided into three main intervals. The first interval corresponds to most of the Early Holocene (11.7-9 cal. kyr BP) when SSTs were warmest and relatively stable (no significant trend), oscillating at around an average value of $\sim 17.2 \pm 1.3^{\circ} \mathrm{C}$ (Fig. $3 b$ ). The second interval displays a general cooling trend of $\sim 4{ }^{\circ} \mathrm{C}$ ending at around $4.2 \mathrm{cal}$. kyr BP when minimum Holocene SSTs were reached $\left(\sim 13.6 \pm 1.2^{\circ} \mathrm{C}\right)$ (Fig. $\left.3 \mathrm{~b}\right)$. The last and most recent interval does not show any clear warming/cooling trend (average SST of $\sim 14.9 \pm 1.2^{\circ} \mathrm{C}$ ) and intense SST oscillations $\left(\sim 2.0^{\circ} \mathrm{C}\right)$ of longer durations than those recorded during previous intervals (Fig. 3b). 
The ALB-2 G. bulloides $\mathrm{Mg} / \mathrm{Ca}$ SST record has been compared to three other SST records from the western Mediterranean Sea that were calculated following the same $\mathrm{Mg} / \mathrm{Ca}$ SST procedure (Fig. 3b-e). The comparison between the four chronology records is very robust (Fig. 2c) and totally independent for the Holocene period (ALB-2 and MD99-2343: this study; ODP976: Combourieu Nebout et al., 2002; MD95-2043: Cacho et al., 1999). The sampling resolution of the ALB-2 record is higher than for the other sites, but the main patterns agree well between all the compared records. Maximum SSTs occurred around $11 \mathrm{cal}$. kyr BP in all records, and also a general cooling trend can be observed during the Early-Middle Holocene, ending in all cases before the Late Holocene (Fig. 3b-e). Absolute values also show a good agreement; when the resolution is high enough, some millennial-scale structures can even be correlated between the four records. This multicore comparison strongly supports the value of $G$. bulloides $\mathrm{Mg} / \mathrm{Ca}$ in this region as an SST proxy and gives confidence that the obtained SST records reflect true regional environmental conditions. Nevertheless, these $\mathrm{Mg} / \mathrm{Ca}$ SST reconstructions show differences from the previous published SST reconstructions based on alkenone measurements that need further discussion (Fig. 3f; Cacho et al., 2001; Martrat et al., 2004, 2014; Jiménez-Amat and Zahn, 2015).

Alkenone SST reconstructions are based on the relative abundance of di- and tri-unsaturated $\mathrm{C}_{37}$ alkenones mostly produced in the Alboran Sea by the marine coccolithophore Emiliania huxleyi (Volkman et al., 1980; Prahl et al., 2000; Ausin et al., 2015). The comparison between $G$. bulloides $\mathrm{Mg} / \mathrm{Ca}$ SST and the alkenone SST (also studied by Jiménez-Amat and Zahn, 2015) shows remarkable differences in both their absolute values and main patterns, even when both proxies are measured for the same core, as observed in core MD95-2043 and also ODP 976 (Fig. 4c and d). For the Holocene, maximum SSTs in the alkenone record were reached later than for the $\mathrm{Mg} / \mathrm{Ca}$ SST records $(\sim 10$ cal. kyr BP), and thenceforth the alkenone SST record shows a rather flat pattern for the whole Holocene, with a slight cooling trend of about $1{ }^{\circ} \mathrm{C}$. In contrast, ALB-2 G. bulloides $\mathrm{Mg} / \mathrm{Ca}$ SST (Fig. 4c-e) shows larger variability over both the short and long term. Holocene absolute SST values in the alkenone record are warmer $\left(20-18^{\circ} \mathrm{C}\right)$ than those recorded by the $\mathrm{Mg} / \mathrm{Ca}$ record $\left(20-13{ }^{\circ} \mathrm{C}\right)$.

Alkenone SST records have been interpreted and calibrated with annual average temperatures (Ternois et al., 1997; Sicre et al., 1999; Prahl, et al., 2000; Cacho et al., 2001; Versteegh et al., 2007; Martrat et al., 2004, 2014). This is consistent with the results from sediment trap series from the western Mediterranean Sea that detect coccolith productivity throughout the year, although enhanced during the spring and autumn seasons and more scarce during the very stratified and oligotrophic summer months (Bárcena et al., 2004; Hernández-Almeida et al., 2011). In contrast, sediment trap studies from the same region indicate that $G$. bulloides has a narrower seasonal window, growing during the spring months (April-May); however, a secondary smaller bloom occurs during autumn (November-December) (Bárcena et al., 2004; Rigual-Hernández et al., 2012). This information fits well with the results of the reviewed G. bulloides $\mathrm{Mg} / \mathrm{Ca}$ calibration for the western Mediterranean (Cisneros et al., 2016). The preferential depth habitat of G. bulloides is above the thermocline within the upper $60 \mathrm{~m}$ of the water column (Schiebel and Hembleben, 2017) as well, because it needs nutrients supplied by vertical mixing (Rao et al., 1988; Hemleben et al., 1989; Kemle-von Mücke and Hemleben, 1999; Bárcena et al., 2004). Present seasonal and depth temperature distribution at the ALB-2 location can be evaluated with the World Ocean Atlas 2013 (Boyer and Mishonov, 2013) data set that averages measurements from 1955 to 2012 (Fig. 4a). Annual average temperatures of $17.8^{\circ} \mathrm{C}$ occur for the upper $10 \mathrm{~m}$ of the water column, in good agreement with core top alkenone SST reconstructions (Fig. 4a). On the other hand, the estimated core top G. bulloides $\mathrm{Mg} / \mathrm{Ca}$ SST of the ALB2 core is $15.5^{\circ} \mathrm{C}$, showing a closer match to the measured temperatures at 25-45 m depth during spring (April-May), in agreement with the main season and depth habitat of G. bulloides (Bárcena et al., 2004; Rigual-Hernández et al., 2012; Schiebel and Hembleben, 2017). The G. bulloides habitat preference has been further tested through the estimation of the theoretical carbonate $\delta^{18} \mathrm{O}$ signal expected for present sea water conditions of the upper $100 \mathrm{mwd}$ (Fig. 4b). This estimation is based on the available data from Pierre (1999), and detailed information on the procedure is provided in the Supplement (Sect. S7). This exercise illustrates that the measured G. bulloides $\delta^{18} \mathrm{O}$ values in the top samples from ALB$2(0.42 \pm 0.1 \% o)$ are indeed comparable to those estimated for April-May from 5 to $40 \mathrm{mwd}$ (Fig. 4b). Therefore, isotopic composition confirms the interpreted G. bulloides habitat of 25-45 m depth during the April-May months based on the $\mathrm{Mg} / \mathrm{Ca}$ data. Consequently, alkenone- $\mathrm{Mg} / \mathrm{Ca}$ SST offset is consistent with the habitat preferences for both season and depth of the two proxy carriers involved, E. huxleyi and $G$. bulloides (Fig. 4a-b).

Another differential feature between the two proxies is the rather smooth behaviour of the alkenone signal, in contrast to the $\mathrm{Mg} / \mathrm{Ca}$ signal (Figs. 3 and 4). This has previously been reported and attributed to the intrinsic characteristics of the proxy measurements (Laepple and Huybers, 2013). The number of individuals that integrate the SST signal in a single measurement is several orders of magnitude larger in the alkenones, averaging the signal of all alkenones contained in the sample, while the $\mathrm{Mg} / \mathrm{Ca}$ analyses average about 40-50 specimens (Laepple and Huybers, 2013). This situation favours the integration of several averaged years in the alkenone SST signal while the $\mathrm{Mg} / \mathrm{Ca}$ SST signal will be more sensitive to a unique season (spring) and with a higher weighting toward the most favourable growth years (Jiménez-Amat and Zahn, 2015). As a consequence, $\mathrm{Mg} / \mathrm{Ca}$ records should result in a higher noise signal but may re- 


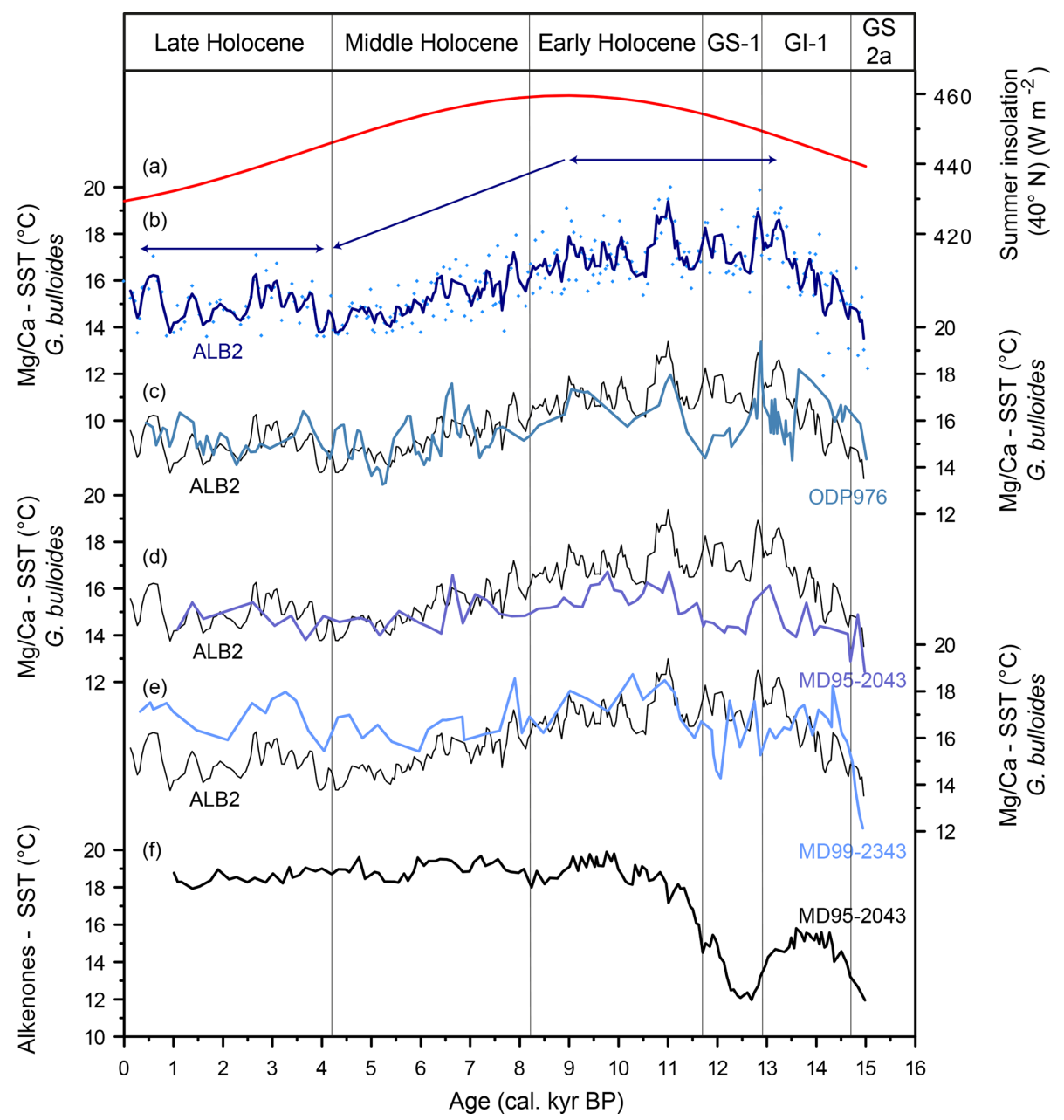

Figure 3. Western Mediterranean SST multi-record comparison for the last 16 cal. $\mathrm{kyr} \mathrm{BP}$. (a) In red, summer insolation at $40^{\circ} \mathrm{N}$; (b) $\mathrm{Mg} / \mathrm{Ca}$ SST $\left({ }^{\circ} \mathrm{C}\right)$ from the ALB-2. Light-blue dots correspond to each SST result; the three-point average is shown by the bold dark-blue line. Dark-blue arrows above the record correspond to the three Holocene intervals described in the text (c, d, e): Mg/Ca SST $\left({ }^{\circ} \mathrm{C}\right)$ from ODP976 (Jiménez-Amat and Zahn, 2015), MD95-2043, and MD99-2343, respectively (bold blue lines), compared with the ALB-2 three-point average $\mathrm{Mg} / \mathrm{Ca} \mathrm{SST}\left({ }^{\circ} \mathrm{C}\right)$ (black line underneath). Note that both records from each plot are plotted on the same $y$ axis. (f) Alkenone SST $\left({ }^{\circ} \mathrm{C}\right)$ from MD95-2043 (Cacho et al., 1999).

flect better extreme changes within single seasons than the alkenone record, whereas seasonal changes may become diluted in the large averaged signal.

In addition, we need to point out that the larger difference between the studied $\mathrm{Mg} / \mathrm{Ca}$ and alkenone SST reconstructions correspond to the deglacial period (at the end of GS1 or the Younger Dryas - YD). Both alkenone and $\mathrm{Mg} / \mathrm{Ca}$ SST records show a cooling of $\sim 3-4{ }^{\circ} \mathrm{C}$ at the onset of the GS-1 (YD), but the big difference occurs at the end of this interval. Both the alkenones and $\mathrm{Mg} / \mathrm{Ca}$ records show an early intra-YD warming (Cacho et al., 2001), and then the alkenone SSTs continue the deglacial warming while the $\mathrm{Mg} / \mathrm{Ca}$ record shows a cooling trend. In order to better explore this discrepancy we have also compared these two records for the glacial period in Fig. 4c-e. G. bulloides $\mathrm{Mg} / \mathrm{Ca}$ SSTs during the last glacial period record the same oscillations and absolute values as do alkenone SSTs, and they both agree on the first warming of the deglaciation, but clearly the second warming phase of deglaciation does not appear in any of the three considered $\mathrm{Mg} / \mathrm{Ca}$ records (Fig. 4c-e). Thus, this is a proxy characteristic that may reflect the limited capacity of $G$. bulloides to adapt to the large temperature change that occurred during deglaciation. $G$. bulloides has different genotypes adapted to different ranges of water temperatures, from transitional to subpolar waters (Kucera and Darling 2002; Kucera et al., 2005), but G. bulloides starts to be scarce in water with temperatures over $20^{\circ} \mathrm{C}$. This agrees with the maximum temperatures recorded during both the glacial and interglacial periods in the $\mathrm{Mg} / \mathrm{Ca}$ records (Fig. 4c-e). Consequently we can interpret that $G$. bulloides has a resilient capacity to change its growth season in order to survive the large deglacial SST changes in 


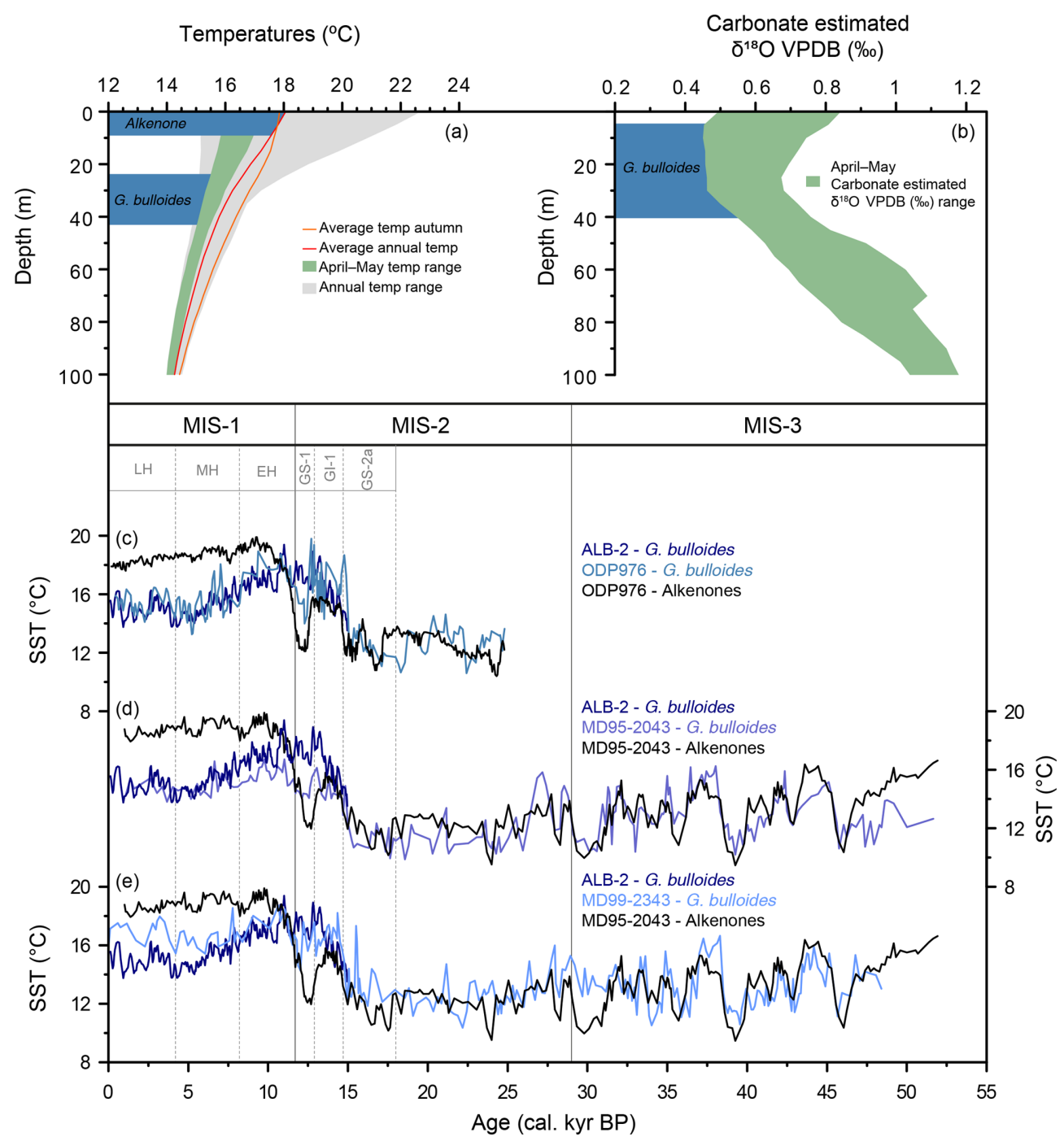

Figure 4. Western Mediterranean SST from alkenone and G. bulloides $\mathrm{Mg} / \mathrm{Ca}$ multi-comparison for the last interglacial and the following (present) interglacial period. (a) Temperatures. (b) Carbonate estimated $\delta^{18} \mathrm{O}$ VPDB (\%o) profile for the first $100 \mathrm{~m}$ from site $503737 \mathrm{~B}$, obtained from WOA13 0.25deg measured during the years 1955-2012 (Boyer and Mishonov, 2013). The horizontal blue band indicates the preferential depth in relation to the profile temperatures (a) and carbonate estimated $\delta^{18} \mathrm{O}$ VPDB (\%o) (b) of G. bulloides (average April-May temperatures and carbonate estimated $\delta^{18} \mathrm{O}$ VPDB $(\% o$ in green) and alkenones (annual average temperatures in red). Note that each of the following comparisons have the same $y$ axis. (c) The blue lines (ALB-2; this study and ODP976; Jiménez-Amat and Zahn, 2015) show G. bulloides $\mathrm{Mg} / \mathrm{Ca}$ SST compared with the alkenone SST (Martrat et al., 2014) from the same ODP976 record. (d) The blue lines (ALB-2 and MD95-2043; both in this study) show G. bulloides Mg/Ca SST compared with the alkenone SSTs from the same MD95-2043 record (Cacho et al., 1999). (e) The blue lines (ALB-2 and MD99-2343; both in this study) show G. bulloides Mg/Ca SST compared with alkenone SST from the MD95-2043 record (Cacho et al., 1999).

the region. We propose that, during the glacial period as well as the first part of deglaciation, G. bulloides could have had its maximum representation during the autumn bloom when upwelling conditions reappeared after the warm sea summer stratification. That could have allowed G. bulloides to grow in a relatively mild upwelling season during the glacial period. Nowadays autumn SST values are comparable to the annual average SST values, and that could explain the comparable SST values of both alkenone and $\mathrm{Mg} / \mathrm{Ca}$ proxies. How- ever the second deglacial warming might have been too extreme for G. bulloides and they would have therefore moved to the spring upwelling bloom with colder SSTs than those during autumn. Consequently we hypothesize that the absence of the second deglacial warming in the G. bulloides $\mathrm{Mg} / \mathrm{Ca}$ record may reflect a resilience strategy to change its habitat toward the spring bloom. At the beginning of the Holocene, when SST variability was lower and within its habitat tolerance, G. bulloides became a good sensor of 
interglacial SST variability (Figs. 3 and 4). Alternatively, it can be argued that $G$. bulloides changed its preferential depth growth habitat in order to survive that large deglacial SST warming. However, in any case, we consider that the shorter deglacial warming of the $\mathrm{Mg} / \mathrm{Ca} \mathrm{SST}$, in contrast to the alkenone SST record, reflects a resilience strategy of G. bulloides rather than reflecting the actual intensity of the deglacial SST warming in the region. In contrast, during the Holocene, the SST changes were within the G. bulloides' range of tolerance, and thus this part of the record should truly record SST changes. It is important to remark that any change in the habitat preference of G. bulloides would have also affected the $\delta^{18} \mathrm{O}$ signal - this is particularly relevant when a temperature correction is applied to this record in order to obtain $\delta^{18} \mathrm{O}_{\mathrm{sw}}$. In that case, the application of the alkenone SST record would introduce a large heavy anomaly in the $\delta^{18} \mathrm{O}_{\text {sw }}$ during deglaciation, and that would reflect the habitat change of one of the proxy carriers rather than actual changes in the regional oceanography. This observation reveals the relevance of using signals $\left(\delta^{18} \mathrm{O}\right.$ and SST) of the same species of foraminifera for such estimations.

\subsection{Holocene evolution in Alboran surface hydrography}

The overall Holocene SST evolution in the Alboran Sea is described in three different phases (Fig. 5c): (a) a maximum SST during the Early Holocene (11-9 cal. kyr BP), (b) a cooling trend throughout the Middle Holocene (94.2 cal. kyr BP), and (c) relatively colder temperatures with intense millennial-scale oscillations for the Late Holocene (4.2-0 cal. kyr BP). This general SST pattern also agrees well with that described for the North Atlantic and western Mediterranean Sea in relation to regional data compilations (Marchal et al., 2002; Kim et al., 2004; Rimbu et al., 2004; Wanner et al., 2008) and with the expected Holocene redistribution of solar energy by the changing orbital configuration according to the atmosphere-ocean general circulation model of Lorenz and Lohmann (2004) (Fig. 5a and c). Nevertheless, the magnitude of the Holocene SST changes in the Alboran Sea (above $5^{\circ} \mathrm{C}$ ) exceeds that expected by simply orbital changes in insolation $\left(\sim 1.6^{\circ} \mathrm{C}\right.$ in atmosphere $)$ (Lorenz and Lohmann, 2004). Therefore, other factors need to be considered to explain the magnitude of the recorded SST changes.

The period of maximum SST in the Alboran Sea (119 cal. kyr BP) occurred while the North Atlantic Ocean was still under the influence of meltwater pulses from the Laurentide ice sheet (Fig. 5b) that injected freshwater over the surface of the North Atlantic Ocean. This situation induced a stratification in the North Atlantic and consequently a weakening of the SPG circulation (Thornalley et al., 2009). At lower latitudes, it has been proposed that the heat transport from the STG toward the North Atlantic was reduced (Repschläger et al., 2017). The consequent heat accumulation in the STG could have hence contributed to a warmer inflow into the Mediterranean Sea and thus may have led to the observed maximum SST in the Alboran Sea (Fig. 5c). But it is also relevant to note that this Early Holocene warm period (11-9 cal. kyr BP) in the Alboran Sea corresponds to the last stage of an organic-rich layer (ORL) formation (Fig. 5e). This ORL has been associated with a strong western Mediterranean stratification phase, resulting from the deglacial sea level rise, which reduced vertical mixing (Cacho et al., 2002; Rogerson et al., 2008). As a consequence of this situation, the modification of Atlantic inflow water along its path into the Mediterranean could have been reduced, thus favouring the persistence of warm conditions in the inflowing subtropical waters.

At around 9 cal. kyr BP, the Alboran SST record (Fig. 5c) starts a progressive cooling trend that culminates in reaching minimum values of around $4.2 \mathrm{cal}$. kyr BP. The onset of this cooling trend is coincident with the development of a wellmixed surface layer (Fig. 5b) in the North Atlantic due to the reduction of deglacial melting (Thornalley et al., 2009). This situation would have allowed enhanced transport of subtropical waters towards higher latitudes, releasing the previous heat accumulation in the STG and potentially leading to cooler water flowing into the Mediterranean Sea. In addition, 9 cal. kyr BP also marked the end of the western Mediterranean stratification phase that led to the formation of the last ORL in the Alboran Sea (Fig. 5e). This end occurred at the time of a strong increase in the speed of deep water currents (Fig. 5d) associated with the formation of the WMDW (Frigola et al., 2007). The reduction in surface stratification in the Alboran Sea would have led to increased water mixing of the inflowing Atlantic waters that could have contributed to the observed cooling trend. This situation was apparently also linked to an increase in the local upwelling conditions developed by the establishment of the western anticyclonic gyre of the Alboran Sea that, according to coccolith assemblages, occurred after $7.7 \mathrm{cal}$. kyr BP (Ausin et al., 2015). In addition, the described SST cooling trend for this period could also have been promoted by some additional atmospheric forcing. Several authors have suggested a southward displacement of North Atlantic westerlies during this period, inducing a southern penetration of winter storm tracks (Desprat et al., 2013; Fletcher et al., 2012; Chabaud et al., 2014; Zielhofer et al., 2017). Therefore, a combination of factors, internal and external to the Alboran Sea, could have accounted for the observed SST cooling trend from $9 \mathrm{kyr}$ until 4.2 cal. kyr BP, when a change occurred in both the shortand long-term variability.

At about $4.2 \mathrm{cal}$. kyr BP a double cold peak structure of a minimum SST occurred (Fig. 5c), reaching $\sim 13.6^{\circ} \mathrm{C}$, representing the minimum values of the record. After this event, the long-term cooling trend ceased while an intense millennial-scale variability developed, involving SST oscillations over $2{ }^{\circ} \mathrm{C}$. This event is apparently synchronous with a peak in the record of deep water current intensity (Fig. 5d), suggesting that deep convection was strengthened 


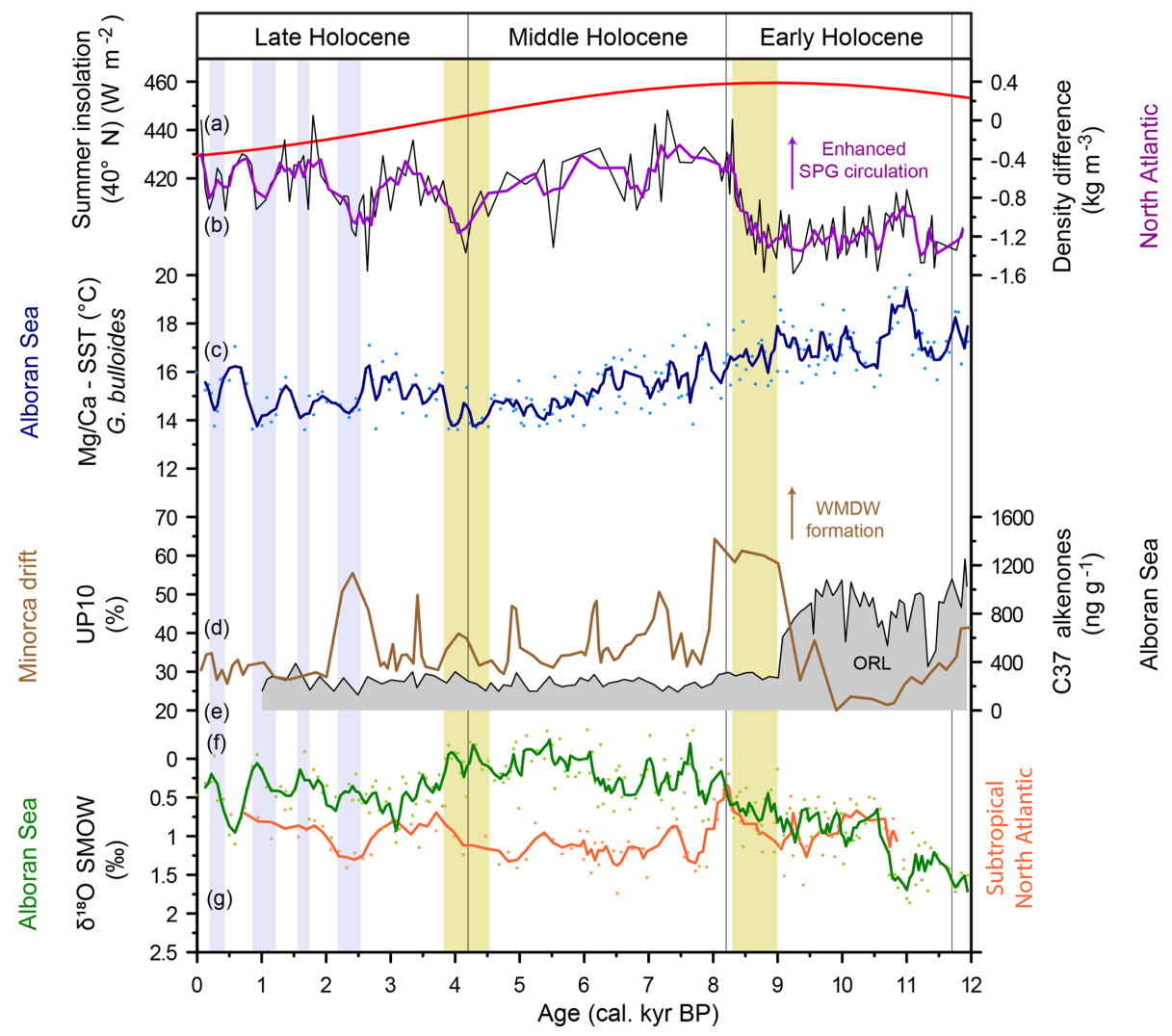

Figure 5. Holocene evolution for the Alboran Sea surface hydrography related to oceanographic processes in the North Atlantic. (a) In red, the summer insolation at $40^{\circ} \mathrm{N}$. (b) In purple, the three-point average of density differences $\left(\mathrm{kg} \mathrm{m}^{-3}\right)$ between G. bulloides and G. inflate from the North Atlantic record RAPiD-12-1K (Thornalley et al., 2009). (c) The new $\mathrm{Mg} / \mathrm{Ca} \mathrm{SST}\left({ }^{\circ} \mathrm{C}\right)$ presented in this work from the ALB-2 (Alboran Sea) - light-blue dots correspond to each SST result and the bold dark-blue line corresponds to the three-point average. (d) In brown, the UP10 fraction (\%) from the Minorca drift core MD99-2343 (Frigola et al., 2007). (e) The grey filled line represents the concentration of $\mathrm{C}_{37}$ alkenones in the Alboran Sea record MD95-2043 (Cacho et al., 2002). (f) In green, the new $\delta^{18} \mathrm{O}_{\mathrm{sw}} \%$ ( $\mathrm{SMOW}$ ) presented in this work from the ALB-2 (Alboran Sea). (g) In orange, the calculated $\delta^{18} \mathrm{O}_{\mathrm{sw}} \%$ (SMOW) from the south Azores record GEOFAR-KF16 (Repschläger et al., 2017). Centred vertical bars: 8.4-9 cal. kyr BP corresponds to the Alboran Sea and North Atlantic synchrony in oceanographic changes; 4.2 cal. kyr BP corresponds to the double peach structure observed for ALB-2 Mg/Ca SST. The four vertical grey bars during the Late Holocene correspond to cold events of the ALB-2 Mg/Ca SST.

in the western Mediterranean Sea during this $4.2 \mathrm{cal}$. kyr BP event but not more than during previous and later Holocene events of this record (Frigola et al., 2007). On the other hand, the North Atlantic record (Fig. 5b) indicates that the $4.2 \mathrm{cal}$. kyr BP event corresponded to one of the Holocene's millennial-scale stratification events, interpreted as a weak mode of SPG circulation (Thornalley et al., 2009). This situation contrasts with that observed during the Early Holocene period, when weak SPG circulation coexisted with maximum SSTs in the Alboran Sea. Interestingly, after the 4.2 cal. kyr BP event, both the Alboran and the North Atlantic records show an intense millennial-scale variability, with minima in Alboran SSTs occurring systematically during periods of weak SPG circulation (Fig. 5b and c). However, further information would be required to establish a mechanism that could potentially link these apparent changes in the Late Holocene AMOC to properties in the Atlantic inflow in the Alboran Sea.

Further insight into the Holocene evolution of the inflowing Atlantic water comes from the ALB- $2 \delta^{18} \mathrm{O}_{\mathrm{sw}}$ reconstruction (Fig. 5f). This record also differentiates three Holocene periods consistent with those defined by the SST record (Fig. 5c). The ALB-2 $\delta^{18} \mathrm{O}_{\mathrm{sw}}$ record is compared with another $\delta^{18} \mathrm{O}_{\mathrm{sw}}$ record (Fig. 5g) that reflects conditions of the subsurface waters from the subtropical gyre (Repschläger et al., 2017). Interestingly, the relationship between these two records changes for the three defined Holocene intervals (Fig. $5 \mathrm{f}$ and g). During the Early Holocene, Alboran waters were comparable to those from the STG, consistent with the previous discussed entrance of subtropical waters, while dominant stratified conditions in the Western Mediterranean preserved the tropical signal. During the Middle Holocene phase, while Alboran SST followed a cooling 
trend, the $\delta^{18} \mathrm{O}_{\mathrm{sw}}$ record oscillates around its lightest values, even lighter than those from the STG during the same period, and this difference became larger across the interval (Fig. $5 \mathrm{f}$ and g). Such a situation suggests that the inflowing Atlantic waters were also fed by some lighter water mass, most likely from a higher-latitude source. This is consistent with the previously discussed enhanced transport of subtropical waters towards higher latitudes during this period that would have led to stronger southward-influenced SPG source waters that would ultimately mix with the Atlantic inflow waters. This situation is consistent with the described intensification of the SPG by Thornalley et al. (2009) and is the dominant influence of subpolar source central waters at intermediate depths in the mid-latitude North Atlantic (Colin et al., 2010). After the $4.2 \mathrm{cal}$. kyr BP event, the STG and Alboran $\delta^{18} \mathrm{O}_{\mathrm{sw}}$ records converge although ALB-2 values remain lighter for most of the interval (Fig. 5f and g). This situation may indicate a reduced southward influence of SPG waters during the Late Holocene, consistent with the interpreted STG source of intermediate waters in the mid-latitude North Atlantic (Colin et al., 2010). The Late Holocene millennial-scale variability is difficult to characterize in this Atlantic-Mediterranean $\delta^{18} \mathrm{O}_{\mathrm{sw}}$ comparison (Fig. $5 \mathrm{f}$ and $\mathrm{g}$ ) due to uncertainties in the relative chronologies and errors in the proxy reconstruction. Thus, further information needs to be explored to ultimately determine the nature of a potential Late Holocene AtlanticMediterranean millennial-scale connection.

\section{Conclusions}

The analysis of $\mathrm{Mg} / \mathrm{Ca}$ SSTs and the $\delta^{18} \mathrm{O}$ from the ALB-2 record have allowed the reconstruction of the paleoceanography of the Alboran Sea during the Holocene and its possible interactions with the Atlantic Ocean. The comparison of new generated oxygen isotopes $\left(\delta^{18} \mathrm{O}\right)$ and $\mathrm{Mg} / \mathrm{Ca}$ SST records from ALB-2 with other western Mediterranean records confirms a common oceanographic signal and suggests the fast modification of the Atlantic inflow water to a more Mediterranean signal, indicating intense surface mixing with the underlying Mediterranean waters.

The western Mediterranean $\mathrm{Mg} / \mathrm{Ca}$ SST signal strongly supports the value of this proxy to reconstruct true regional environmental conditions, despite significant differences that emerge when it is compared to previously published alkenone SST records. This proxy comparison is extended to the glacial period, which reveals a major proxy difference during deglaciation, particularly during the second warming phase after the YD period, which is nearly absent in all the $\mathrm{Mg} / \mathrm{Ca}$ SST records. This damped warming in the $\mathrm{Mg} / \mathrm{Ca}$ record reflects the resilient capacity of G. bulloides to change the growth season in order to compensate for the large SST deglacial warming. Therefore, during the last glacial period as well as for the first part of deglaciation, G. bulloides mostly grew during the milder upwelling sea- son (autumn), while, after the YD, G. bulloides minimized the impact of the warming by mostly developing during the colder upwelling season (spring), which is also the present situation. In contrast, during the Holocene, SST variability is far larger in the $\mathrm{Mg} / \mathrm{Ca} S \mathrm{ST}$ record $\left(\sim 5^{\circ} \mathrm{C}\right)$ than for the alkenone SST record $\left(\sim 2^{\circ} \mathrm{C}\right)$. We interpreted this $\mathrm{Mg} / \mathrm{Ca}$ SST variability as a true climate evolution for a single season (spring), whereas the reduced variability in the alkenone SST reflects a well-averaged annual signal.

The new high-resolution Holocene $\mathrm{Mg} / \mathrm{Ca}$ SST record differentiates three intervals according to its main patterns: (1) the warmest SST values occurred during the Early Holocene (11.7-9 cal. kyr BP); (2) during the Middle Holocene, there was a continuous cooling trend that culminated with the coldest Holocene SST with a double cold peak structure centred at around $4.2 \mathrm{cal}$. kyr BP; (3) the Late Holocene (4.2 cal. kyr BP-present) did not follow any clear cooling/warming trend, but millennial-scale oscillations were enhanced. This general Holocene SST evolution matches to some extent of solar energy redistribution by the changing orbital configuration; nevertheless, the intensity of the changes and the short-term variability requires the action of some other factors.

The warmest SST of the Early Holocene (11-9 cal. kyr BP) occurred while intense meltwater pulses from the Laurentide ice sheet could have led to a reduction in the northward heat transport from the STG towards the North Atlantic, and the consequent heat accumulation could have contributed to the warm inflow to the Mediterranean Sea. The onset of the cooling trend occurred at $9 \mathrm{cal} . \mathrm{kyr} \mathrm{BP}$, and the relative evolution of the $\delta^{18} \mathrm{O}_{\text {sw }}$ records from the Alboran Sea and the STG suggest the arrival through Gibraltar of light waters from northern latitudes, supporting an enhanced influence of highlatitude North Atlantic conditions in the inflowing waters to the Mediterranean Sea.

The 4.2 cal. kyr BP event is recorded in the $\mathrm{Mg} / \mathrm{Ca}$ SST as a double cold peak event, reaching the lowest SST of the Holocene; it ended the cooling trend of the previous interval. This $4.2 \mathrm{cal}$. kyr BP event marks the onset of an intense millennial-scale variability that dominated during the Late Holocene and that coincides with an event of intense WMDW formation. Comparable millennial-scale variability has been previously described further north in the North Atlantic Ocean, in relation to the intensity of the SPG. The latest connections between these North Atlantic changes and the Alboran Sea need further information to be fully understood, but our observations highlight that the AtlanticMediterranean connections through the inflow waters operated in a different way during the Early and Late Holocene.

Data availability. Data produced in this paper can be found via the following links. HER-GC-ALB-2 age model: https://doi.org/10.1594/PANGAEA.901744 (Català et al., 2019a). HER-GC-ALB-2 $\delta^{18} \mathrm{O}$ : 
https://doi.org/10.1594/PANGAEA.901663 (Català et al., 2019b). HER-GC-ALB-2 sea surface temperatures and $\mathrm{Mg} / \mathrm{Ca}$ data: https://doi.org/10.1594/PANGAEA.901666c (Català et al., 2019). MD99-2343 age model update: https://doi.org/10.1594/PANGAEA.901685d (Català et al., 2019). MD99-2343 sea surface temperatures and $\mathrm{Mg} / \mathrm{Ca}$ data: https://doi.org/10.1594/PANGAEA.901678e (Català et al., 2019). MD95-2043 sea surface temperatures and $\mathrm{Mg} / \mathrm{Ca}$ data: https://doi.org/10.1594/PANGAEA.901746f (Català et al., 2019).

Supplement. The supplement related to this article is available online at: https://doi.org/10.5194/cp-15-927-2019-supplement.

Competing interests. The authors declare that they have no conflict of interest.

Acknowledgements. This research has been financially supported by the ERC Consolidator Grant TIMED (683237) and CHIMERA project (CTM2016-75411-R). Core ALB-2 was recovered by the HERMESIONE expedition on board R/V Hespérides in 2009. The GRC Geociències Marines thank the Generalitat de Catalunya for the Grups de Recerca Consolidats grant 2017 SGR 315. Leopoldo D. Pena acknowledges support from the Ramón y Cajal program (MINECO, Spain). Isabel Cacho thanks the ICREA Academia programme from the Generalitat de Catalunya. We are grateful to Montse Guart (Dept. Dinàmica de la Terra i de l'Oceà, Universitat de Barcelona), Maite Romero, Antoni Padró, and Joaquím Perona (Centres Científics i Tecnològics, CCiT-UB) for technical support and Grant George Buffett for language improvements. We also acknowledge the guest editor and the anonymous reviewers for their comments, which improved this paper.

Review statement. This paper was edited by Raymond Bradley and reviewed by three anonymous referees.

\section{References}

Andrews, J. T., Hardadottir, J., Stoner, J. S., Mann, M. E., Kristjansdottir, G. B., and Koc, N.: Decadal to millennial-scale periodicities in North Iceland shelf sediments over the last 12 000 cal yr: long-term North Atlantic oceanographic variability and solar forcing, Earth Planet. Sc. Lett., 210, 453-465, https://doi.org/10.1016/S0012-821X(03)00139-0, 2003.

Ausin, B., Flores, J. A., Sierro, F. J., Cacho, I., HernándezAlmeida, I., Martrat, B., and Grimalt, J. O.: Atmospheric patterns driving Holocene productivity in the Alboran Sea (Western Mediterranean): A multiproxy approach, Holocene, 25, 583-595, https://doi.org/10.1177/0959683614565952, 2015.

Bárcena, M. A., Flores, J. A., Sierro, F. J., Pérez-Folgado, M., Fabres, J., Calafat, A., and Canals, M.: Planktonic response to main oceanographic changes in the Alboran Sea (Western Mediterranean) as documented in sediment traps and surface sediments, Mar. Micropaleontol., 53, 423-445, https://doi.org/10.1016/j.marmicro.2004.09.009, 2004.
Barker, S., Greaves, M., and Elderfield, H.: A study of cleaning procedures used for foraminiferal $\mathrm{Mg} / \mathrm{Ca}$ paleothermometry, Geochem. Geophy. Geosy., 4, 1-20, https://doi.org/10.1029/2003GC000559, 2003.

Bartlein, P. J., Harrison, S. P., Brewer, S., Connor, S., Davis, B. A. S., Gajewski, K., Guiot, J., Henderson, A., Peyron, O., Prentice, I. C., Scholze, M., Seppä, H., Shuman, B., Sugita, S., Thompson, R. S., Viau, A. E., Williams, J., and Wu, H.: Pollen-based continental climate reconstructions at 6 and $21 \mathrm{ka}$ : a global synthesis, Clim. Dynam., 37, 775-802, https://doi.org/10.1007/s00382010-0904-1, 2011.

Béthoux, J. P.: Mean water fluxes across sections in the Mediterranean Sea, evaluated in the basis of water and salt budgets and of observed salinities, Oceanol. Acta, 3, 79-88, 1980.

Blaauw, M. and Christen, J. A.: Flexible paleoclimate age-depth models using an autoregressive gamma process, Bayesian Anal., 6, 457-474, https://doi.org/10.1214/11-BA618, 2011.

Bond, G., Showers, W., Cheseby, M., Lotti, R., Almasi, P., DeMenocal, P., Priore, P., Cullen, H., Hajdas, I., and Bonani, G.: A Pervasive Millennial-Scale Cycle in North Atlantic Holocene and Glacial Climates, Science, 278, 1257-1266, https://doi.org/10.1126/science.278.5341.1257, 1997.

Bond, G., Kromer, B., Beer, J., Muscheler, R., Evans, M. N., Showers, W., Hoffmann, S., Lotti-Bond, R., Hajdas, I., and Bonani, G.: Persistent Solar Influenceon North Atlantic Climate During the Holocene, Science, 294, 2130-2136, https://doi.org/10.1126/science.1065680, 2001.

Böning, C. W., Scheinert, M., Dengg, J., Biastoch, A., and Funk, A.: Decadal variability of subpolar gyre transport and its reverberation in the North Atlantic overturning, Geophys. Res. Lett., 33, 1-5, https://doi.org/10.1029/2006GL026906, 2006.

Boyer, T. and Mishonov, A.: 14 pp., World Ocean Atlas 2013 Product Documentation, 2013.

Bray, N. A., Ochoa, J., and Kinder, T. H.: The role of the interface exchange through the Strait of Gibraltar, J. Geophys. Res., 100, 10755-10176, https://doi.org/10.1029/95JC00381, 1995.

Cacho, I., Grimalt, J. O., Pelejero, C., Canals, M., Sierro, F. J., Flores, J. A., and Shackleton, N.: Dansgaard-Oeschger and Heinrich event imprints in Alboran Sea paleotemperatures, Paleoceanography, 14, 698-705, https://doi.org/10.1029/1999PA900044, 1999.

Cacho, I., Grimalt, J. O., Canals, M., Sbaffi, L., Shackleton, N. J., Schönfeld, J., and Zahn, R.: Variability of the western Mediterranean Sea surface temperature during the last 25,000 years and its connection with the Northern Hemisphere climatic changes, Paleoceanography, 16, 40-52, https://doi.org/10.1029/2000PA000502, 2001.

Cacho, I., Grimalt, J. O., and Canals, M.: Response of the Western Mediterranean Sea to rapid climatic variability during the last 50,000 years: A molecular biomarker approach, J. Mar. Syst., 33-34, 253-272, https://doi.org/10.1016/S0924-7963(02)00061$1,2002$.

Català, A., Cacho, I., Frigola, J., Peña, L. D., Lirer, F.: Deglacial and Holocene sea surface temperature (SST) and $\delta^{18} \mathrm{O}$ reconstruction from the western Mediterranean Sea, PANGAEA, https://doi.org/10.1594/PANGAEA.901667, 2019a.

Català, A., Cacho, I., Frigola, J., Peña, L. D., Lirer, F.: Stable Isotopes $\left(\delta^{18} \mathrm{O}\right)$ analysis of $\mathrm{G}$. bulloides from 
sediment core HER-GC-ALB2 (ALB-2), PANGAEA, https://doi.org/10.1594/PANGAEA.901663, 2019b.

Català, A., Cacho, I., Frigola, J., Peña, L. D., Lirer, F.: Sea surface temperature (SST) and $\mathrm{Mg} / \mathrm{Ca}$ analysis of $\mathrm{G}$. bulloides from sediment core HER-GC-ALB2 (ALB-2), PANGAEA, https://doi.org/10.1594/PANGAEA.901666, 2019c.

Català, A., Cacho, I., Frigola, J., Peña, L. D., Lirer, F.: Agemodel update from sediment core MD99-2343, PANGAEA, https://doi.org/10.1594/PANGAEA.901685, 2019d.

Català, A., Cacho, I., Frigola, J., Peña, L. D., Lirer, F.: Sea surface temperature (SST) and $\mathrm{Mg} / \mathrm{Ca}$ analysis of G. bulloides from sediment core MD99-2343, PANGAEA, https://doi.org/10.1594/PANGAEA.901678, 2019d.

Català, A., Cacho, I., Frigola, J., Peña, L. D., Lirer, F.: Sea surface temperature (SST) and $\mathrm{Mg} / \mathrm{Ca}$ analysis of G. bulloides from sediment core MD95-2043, PANGAEA, https://doi.org/10.1594/PANGAEA.901746, 2019e.

Chabaud, L., Sánchez Goñi, M. F., Desprat, S., and Rossignol, L.: Land-sea climatic variability in the eastern North Atlantic subtropical region over the last 14,200 years: Atmospheric and oceanic processes at different timescales, Holocene, 24, 787797, https://doi.org/10.1177/0959683614530439, 2014.

Cisneros, M., Cacho, I., Frigola, J., Canals, M., Masqué, P., Martrat, B., Casado, M., Grimalt, J. O., Pena, L. D., Margaritelli, G., and Lirer, F.: Sea surface temperature variability in the central-western Mediterranean Sea during the last 2700 years: a multi-proxy and multi-record approach, Clim. Past, 12, 849-869, https://doi.org/10.5194/cp-12-849-2016, 2016.

Cléroux, C., Debret, M., Cortijo, E., Duplessy, J.-C., Dewilde, F., Reijmer, J., and Massei, N.: High-resolution sea surface reconstructions off Cape Hatteras over the last $10 \mathrm{ka}$, Paleoceanography, 27, 1-14, https://doi.org/10.1029/2011PA002184, 2012.

Colin, C., Frank, N., Copard, K., and Douville, E.: Neodymium isotopic composition of deep-sea corals from the NE Atlantic: implications for past hydrological changes during the Holocene, Quaternary Sci. Rev., 29, 2509-2517, https://doi.org/10.1016/j.quascirev.2010.05.012, 2010.

Combourieu Nebout, N., Turon, J., Zahn, R., Capotondi, L., Londeix, L., and Pahnke, K.: Enhanced aridity and atmospheric high-pressure stability over the western Mediterranean during the North Atlantic cold events of the past 50 k.y., Geology, 30, 863866, 2002.

Combourieu Nebout, N., Peyron, O., Dormoy, I., Desprat, S., Beaudouin, C., Kotthoff, U., and Marret, F.: Rapid climatic variability in the west Mediterranean during the last 25000 years from high resolution pollen data, Clim. Past, 5, 503-521, https://doi.org/10.5194/cp-5-503-2009, 2009.

Coplen, T. B.: New guidelines for reporting stable hydrogen, carbon, and oxygen isotope-ratio data, Geochim. Cosmochim. Ac., 60, 3359-3360, https://doi.org/10.1016/0016-7037(96)00263-3, 1996.

Craig, H.: The measurement of oxygen isotope paleotemperatures, in: Stable Isotopes in Oceanographic Studies and Paleotemperatures, edited by: Tongiorgi, E., Consiglio Nazionale delle Ricerche, Laboratorio di Geologia Nucleare, Pisa, 1-24, 1965.

Debret, M., Bout-Roumazeilles, V., Grousset, F., Desmet, M., McManus, J. F., Massei, N., Sebag, D., Petit, J.-R., Copard, Y., and Trentesaux, A.: The origin of the 1500-year climate cy- cles in Holocene North-Atlantic records, Clim. Past, 3, 569-575, https://doi.org/10.5194/cp-3-569-2007, 2007.

Debret, M., Sebag, D., Crosta, X., Massei, N., Petit, J.-R., Chapron, E., and Bout-Roumazeilles, V.: Evidence from wavelet analysis for a mid-Holocene transition in global climate forcing, Quaternary Sci. Rev., 28, 2675-2688, https://doi.org/10.1016/j.quascirev.2009.06.005, 2009.

Desprat, S., Combourieu-Nebout, N., Essallami, L., Sicre, M. A., Dormoy, I., Peyron, O., Siani, G., Bout Roumazeilles, V., and Turon, J. L.: Deglacial and Holocene vegetation and climatic changes in the southern Central Mediterranean from a direct land-sea correlation, Clim. Past, 9, 767-787, https://doi.org/10.5194/cp-9-767-2013, 2013.

Elderfield, H. and Ganssen, G.: Past temperature and delta180 of surface ocean waters inferred from foraminiferal $\mathrm{Mg} / \mathrm{Ca}$ ratios, Nature, 405, 442-445, https://doi.org/10.1038/35013033, 2000.

Fabres, J., Calafat, A., Sanchez-Vidal, A., Canals, M., and Heussner, S.: Composition and spatio-temporal variability of particle fluxes in the Western Alboran Gyre, Mediterranean Sea, J. Marine Syst., 33-34, 431-456, doi.org/10.1016/S09247963(02)00070-2, 2002.

Ferguson, J. E., Henderson, G. M., Kucera, M., and Rickaby, R. E. M.: Systematic change of foraminiferal $\mathrm{Mg} / \mathrm{Ca}$ ratios across a strong salinity gradient, Earth Planet. Sc. Lett., 265, 153-166, https://doi.org/10.1016/j.epsl.2007.10.011, 2008.

Fiúza, A. F. G.: Hidrologia e dinamica das aguas costeiras de Portugal, PhD Thesis, Universidade de Lisboa, 1984.

Fletcher, W. J., Debret, M., and Sanchez-Goñi, M.-F.: MidHolocene emergence of a low-frequency millennial oscillation in western Mediterranean climate: Implications for past dynamics of the North Atlantic atmospheric westerlies, Holocene, 0, 1-14, https://doi.org/10.1177/0959683612460783, 2012.

Frigola, J., Moreno, A., Cacho, I., Canals, M., Sierro, F. J., Flores, J. A., Grimalt, J. O., Hodell, D. A., and Curtis, J. H.: Holocene climate variability in the western Mediterranean region from a deepwater sediment record, Paleoceanography, 22, 2209, https://doi.org/10.1029/2006PA001307, 2007.

Frigola, J., Moreno, A., Cacho, I., Canals, M., Sierro, F. J., Flores, J. A., and Grimalt, J. O.: Evidence of abrupt changes in Western Mediterranean Deep Water circulation during the last 50 kyr: A high-resolution marine record from the Balearic Sea, Quatern. Int., 181, 88-104, https://doi.org/10.1016/j.quaint.2007.06.016, 2008.

Gao, Y.-Q. and Yu, L.: Subpolar Gyre Index and the North Atlantic Meridional Overturning Circulation in a Coupled Climate Model, Atmos. Ocean. Sci. Lett., 1, 29-32, 2008.

Giraudeau, J., Grelaud, M., Solignac, S., Andrews, J. T., Moros, M., and Jansen, E.: Millennial-scale variability in Atlantic water advection to the Nordic Seas derived from Holocene coccolith concentration records, Quaternary Sci. Rev., 29, 1276-1287, https://doi.org/10.1016/j.quascirev.2010.02.014, 2010.

Hemleben, C., Spindler, M., and Roger Anderson, O.: Modern Planktonic Foraminifera, Spinger, https://doi.org/10.1007/978-14612-3544-6, 1989.

Hernández-Almeida, I., Bárcena, M. A., Flores, J. A., Sierro, F. J., Sanchez-Vidal, A., and Calafat, A.: Microplankton response to environmental conditions in the Alboran Sea (Western Mediterranean): One year sediment trap record, Mar. Micropaleon- 
tol., 78, 14-24, https://doi.org/10.1016/j.marmicro.2010.09.005, 2011.

Hönisch, B., Allen, K. A., Lea, D. W., Spero, H. J., Eggins, S. M., Arbuszewski, J., DeMenocal, P., Rosenthal, Y., Russell, A. D., and Elderfield, H.: The influence of salinity on $\mathrm{Mg} / \mathrm{Ca}$ in plank- tic foraminifers - evidence from cultures, core-top sediments and complementary $\delta 18 \mathrm{O}$, Geochim. Cosmochim. Ac., 121, 196-213, 2013.

Hoogakker, B. A. A., Klinkhammer, G. P., Elderfield, H., Rohling, E. J., and Hayward, C.: $\mathrm{Mg} / \mathrm{Ca}$ paleothermometry in high salinity environments, Earth Planet. Sc. Lett., 284, 583-589, https://doi.org/10.1016/j.epsl.2009.05.027, 2009.

Jalali, B., Sicre, M.-A., Bassetti, M.-A., and Kallel, N.: Holocene climate variability in the North-Western Mediterranean Sea (Gulf of Lions), Clim. Past, 12, 91-101, https://doi.org/10.5194/cp-1291-2016, 2016.

Jalali, B., Sicre, M.-A., Azuara, J., Pellichero, V., and CombourieuNebout, N.: Influence of the North Atlantic subpolar gyre circulation on the $4.2 \mathrm{kaBP}$ event, Clim. Past, 15, 701-711, https://doi.org/10.5194/cp-15-701-2019, 2019.

Jiménez-Amat, P. and Zahn, R.: Offset timing of climate oscillations during the last two glacial-interglacial transitions connected with large-scale freshwater perturbation, Paleoceanography, 30, 768788, https://doi.org/10.1002/2014PA002710, 2015.

Kemle-von Mücke, S. and Hemleben, C.: Foraminifera, in: South Atlantic Zooplankton, edited by: Boltovskoy, D., Backhuys Publishers, Leiden, the Netherlands, 1999.

Kim, J.-H., Rimbu, N., Lorenz, S. J., Lohmann, G., Nam, S., Schouten, S., Ru, C., and Schneider, R. R.: North Pacific and North Atlantic sea-surface temperature variability during the Holocene, Quaternary Sci. Rev., 23, 2141-2154, https://doi.org/10.1016/j.quascirev.2004.08.010, 2004.

Kucera, M. and Darling, K. F.: Cryptic species of planktonic foraminifera: their effect on palaeoceanographic reconstructions, Philos. T. Roy. Soc. A, 360, 695-718, https://doi.org/10.1098/rsta.2001.0962, 2002.

Kucera, M., Weinelt, M., Kiefer, T., Pflaumann, U., Hayes, A., Weinelt, M., Chen, M. Te, Mix, A. C., Barrows, T. T., Cortijo, E., Duprat, J., Juggins, S., and Waelbroeck, C.: Reconstruction of sea-surface temperatures from assemblages of planktonic foraminifera: multi-technique approach based on geographically constrained calibration data sets and its application to glacial Atlantic and Pacific Oceans, Quaternary Sci. Rev., 24, 951-998, https://doi.org/10.1016/j.quascirev.2004.07.014, 2005.

Lacombe, H., Gascard, J. C, Cornella, J., and Béthoux, J. P.: Response ofthe Mediterranean to the water and energy fluxes across its surface, on seasonal and interannual scales, Oceanol. Acta, 4, 247-255, 1981.

Laepple, T. and Huybers, P.: Reconciling discrepancies between Uk37 and $\mathrm{Mg} / \mathrm{Ca}$ reconstructions of Holocene marine temperature variability, Earth Planet. Sc. Lett., 375, 418-429, 2013.

Lionello, P., Malanotte-Rizzoli, P., Boscolo, R., Alpert, P., Artale, V., Li, L., Luterbacher, J., May, W., Trigo, R., Tsimplis, M., Ulbrich, U., and Xoplaki, E.: The Mediterranean climate: An overview of the main characteristics and issues, Dev. Earth Environ. Sci., 4, 1-26, https://doi.org/10.1016/S15719197(06)80003-0, 2006.

Lorenz, S. J. and Lohmann, G.: Acceleration technique for Milankovitch type forcing in a coupled atmosphere-ocean circula- tion model: method and application for the Holocene, Clim. Dynam., 23, 727-743, https://doi.org/10.1007/s00382-004-0469-y, 2004.

Marchal, O., Cacho, I., Stockera, T. F., Grimalt, J. O., Calvo, E., Martrat, B., Shackleton, N., Vautravers, M., Cortijo, E., Kreveld, S. van, Andersson, C., Koç, N., Chapman, M., Sbaffi, L., Duplessy, J.-C., Sarnthein, M., Turon, J.-L., Duprat, J., and Jansen, E.: Apparent long-termcooling of the sea surface in the northeast Atlantic and Mediterranean during the Holocene, Quaternary Sci. Rev., 21, 455-483, https://doi.org/10.1016/S02773791(01)00105-6, 2002.

Marchitto, T. M. and DeMenocal, P. B.: Late Holocene variability of upper North Atlantic Deep Water temperature and salinity, Geochem. Geophy. Geosy., 4, 1100, https://doi.org/10.1029/2003GC000598, 2003.

Martrat, B., Grimalt, J. O., Lopez-Martínez, C., Cacho, I., Sierro, F. J., Flores, J. A., Zhang, R., Canals, M., Curtis, J. H., and Hodell, D. A.: Abrupt Temperature changes in the Western Mediterranean oer the past 250,000 years, Science, 306, 1762-1765, https://doi.org/10.1126/science.1101706, 2004.

Martrat, B., Jimenezamat, P., Zahn, R., and Grimalt, J. O.: Similarities and dissimilarities between the last two deglaciations and interglaciations in the North Atlantic region, Quaternary Sci. Rev., 99, 122-134, https://doi.org/10.1016/j.quascirev.2014.06.016, 2014.

Millot, C.: Circulation in the Western Mediterranean Sea, J. Mar. Syst., 20, 423-442, https://doi.org/10.1016/S09247963(98)00078-5, 1999.

Millot, C.: Progress in Oceanography Another description of the Mediterranean Sea outflow, Prog. Oceanogr., 82, 101-124, https://doi.org/10.1016/j.pocean.2009.04.016, 2009.

Moreno, A., Cacho, I., Canals, M., Prins, M. A., SánchezGoñi, M.-F., Grimalt, J. O., and Weltje, G. J.: Saharan Dust Transport and High-Latitude Glacial Climatic Variability: The Alboran Sea Record, Quaternary Res., 58, 318-328, https://doi.org/10.1006/qres.2002.2383, 2002.

Moros, M., Emeis, K., Risebrobakken, B., Snowball, I., Kuijpers, A., McManus, J., and Jansen, E.: Sea surface temperatures and ice rafting in the Holocene North Atlantic: climate influences on northern Europe and Greenland, Quaternary Sci. Rev., 23, 2113 2126, https://doi.org/10.1016/j.quascirev.2004.08.003, 2004.

Nieto-Moreno, V., Martínez-Ruiz, F., Giralt, S., Jiménez-Espejo, F., Gallego-Torres, D., Rodrigo-Gámiz, M., García-Orellana, J., Ortega-Huertas, M., and de Lange, G. J.: Tracking climate variability in the western Mediterranean during the Late Holocene: a multiproxy approach, Clim. Past, 7, 1395-1414, https://doi.org/10.5194/cp-7-1395-2011, 2011.

Pena, L. D., Calvo, E., Cacho, I., Eggins, S., and Pelejero, C.: Identification and removal of Mn-Mg-rich contaminant phases on foraminiferal tests: Implications for $\mathrm{Mg} / \mathrm{Ca}$ past temperature reconstructions, Geochem. Geophy. Geosy., 6, Q09P02, https://doi.org/10.1029/2005GC000930, 2005.

Pierre, C.: The oxygen and carbon isotope distribution in the Mediterranean water masses, Mar. Geol., 153, 41-55, 1999.

Prahl, F., Herbert, T., Brassell, S. C., Ohkouchi, N., Pagani, M., Repeta, D., Rosell-Melé, A., and Sikes, E.: Status of alkenone paleothermometer calibration: Report from Working Group 3, Geochem. Geophy. Geosy., 1, 2000GC000058, https://doi.org/10.1029/2000GC000058, 2000. 
Rao, K. K., Paulinose, V. T., Jayalakshmy, K. V., Panikkar, B. M., and Krishnan Kutty, M.: Distribution of Living Planktonic Foraminifera in the Coastal Upwelling Region of Kenya, Africa, Indian J. Mar. Sediments, 17, 121-127, 1988.

Reimer, P. J., Bard, E., Bayliss, A., Beck, J. W., Blackwell, P. G., Bronk, C., Caitlin, R., Hai, E. B., Edwards, R Lawrence Friedrich, M., Grootes, P. M., Guilderson, T. P., Haflidason, H., Hajdas, I., Hatté, C., Heaton, T. J., Hoffmann, D. L., Hogg, A. G., Hughen, K. A., Kaiser, K. F., Kromer, B., Manning, S. W., Niu, M., Reimer, R. W., Richards, D. A., Scott, E. M., Southon, J. R., Staff, R. A., Turney, C. S. M., and van der Plicht, J.: Intcal13 and marine13 radiocarbon age calibration curves 0-50 000 Years cal BP, Radiocarbon, 55, 1869-1887, https://doi.org/10.2458/azu_js_rc.55.16947, 2013.

Repschläger, J., Garbe-Schönberg, D., Weinelt, M., and Schneider, R.: Holocene evolution of the North Atlantic subsurface transport, Clim. Past, 13, 333-344, https://doi.org/10.5194/cp13-333-2017, 2017.

Rigual-Hernández, A. S., Sierro, F. J., Bárcena, M. A., Flores, J. A., and Heussner, S.: Seasonal and interannual changes of planktic foraminiferal fluxes in the Gulf of Lions (NW Mediterranean) and their implications for paleoceanographic studies: two 12year sediment trap records, Deep-Sea Res. Pt. I, 66, 26-40, https://doi.org/10.1016/j.dsr.2012.03.011, 2012.

Rimbu, N., Lohmann, G., Lorenz, S. J., Kim, J. H., and Schneider, R. R.: Holocene climate variability as derived from alkenone sea surface temperature and coupled oceanatmosphere model experiments, Clim. Dynam., 23, 215-227, https://doi.org/10.1007/s00382-004-0435-8, 2004.

Roberts, N., Moreno, A., Valero-Garcés, B. L., Corella, J. P., Jones, M., Allcock, S., Woodbridge, J., Morellón, M., Luterbacher, J., Xoplaki, E., and Türkeş, M.: Palaeolimnological evidence for an east-west climate see-saw in the Mediterranean since AD 900, Global Planet. Change, 84-85, 23-34, https://doi.org/10.1016/j.gloplacha.2011.11.002, 2012.

Rodrigo-Gámiz, M., Martínez-Ruiz, F., Jiménez-Espejo, F. J., Gallego-Torres, D., Nieto-Moreno, V., Romero, O., and Ariztegui, D.: Impact of climate variability in the western Mediterranean during the last 20,000 years: oceanic and atmospheric responses, Quaternary Sci. Rev., 30, 2018-2034, https://doi.org/10.1016/j.quascirev.2011.05.011, 2011.

Rodrigo-Gámiz, M., Martínez-Ruíz, F., Rampen, S. W., Schouten, S., and Sinninghe Damsté, J. S.: Sea surface temperature variations in the western Mediterranean Sea over the last 20 kyr: A dual-organic proxy (UK'37 and LDI) approach, Paleoceanography, 29, 87-98, https://doi.org/10.1002/2013PA002466, 2014

Rogerson, M., Cacho, I., Jimenez-Espejo, J., Reguera, M. I., Sierro, F. J., Martinez-Ruiz, F., Frigola, J., and Canals, M.: A dynamic explanation for the origin of the western Mediterranean organic-rich layers, Geochem. Geophy. Geosy., 9, Q07U01, https://doi.org/10.1029/2007GC001936, 2008.

Rosenthal, Y., Perron-Cashman, S., Lear, C. H., Bard, E., Barker, S., Billups, K., Bryan, M., Delaney, M., deMenocal, P. B., Dwyer, G. S., Elderfield, H., German, C. R., Greaves, M., Lea, D. W., Marchitto Jr, T. M., Pak, D. K., Paradis, G. L., Russell, A. D., Schneider, R. R., Scheiderich, K., Stott, L., Tachikawa, K., Tappa, E., Thunell, R., Wara, M., Weldeab, S., and Wilson, P. A.: Interlaboratory comparison study of $\mathrm{Mg} / \mathrm{Ca}$ and $\mathrm{Sr} / \mathrm{Ca}$ measurements in planktonic foraminifera for paleo- ceanographic research, Geochem. Geophy. Geosy., 5, Q04D09, https://doi.org/10.1029/2003GC000650, 2004

Sabatier, P., Dezileau, L., Colin, C., Briqueu, L., Bouchette, F., Martinez, P., Siani, G., Raynal, O., and Von Grafenstein, U.: 7000 years of paleostorm activity in the NW Mediterranean Sea in response to Holocene climate events, Quaternary Res., 77, 1-11, https://doi.org/10.1016/j.yqres.2011.09.002, 2012.

Schiebel, C. and Hemleben, C.: Planktic Foraminifers in the Modern Ocean, Springer, https://doi.org/10.1007/978-3-662-502976, 2017.

Shackleton, N.: Attainment of isotopic equilibrium between ocean water and the benthonic foraminifera genus Uvigerina: isotopic changes in the ocean during the last glacial, CNRS, Colloq. Int., 219, 203-209, 1974

Sicre, M.-A., Ternois, Y., Miquel, J.-C., and Marty, J.-C.: Alkenones in the Northwestern Mediterranean sea: interannual variability and vertical transfer, Geiohysical Res. Lett., 26, 1735-1738, https://doi.org/10.1029/1999GL900353, 1999.

Sierro, F. J., Hodell, D. A., Curtis, J. H., Flores, J. A., Reguera, I., Colmenero-Hidalgo, E., Bárcena, M. A., Grimalt, J. O., Cacho, I., Frigola, J., and Canals, M.: Impact of iceberg melting on Mediterranean thermohaline circulation during Heinrich events, Paleoceanography, 20, 1-13, https://doi.org/10.1029/2004PA001051, 2005.

Ternois, Y., Sicre, M.-A., Boireau, A., Contes, M. H., and Eglinton, G.: Evaluation of long-chain alkenones as paleo-temperature indicators in the Mediterranean Sea, Deep. Res. Pt. I, 44, 271-286, https://doi.org/10.1016/S0967-0637(97)89915-3, 1997.

Thornalley, D. J. R., Elderfield, H., and McCave, I. N.: Holocene oscillations in temperature and salinity of the surface subpolar North Atlantic, Nature, 457, 711-714, https://doi.org/10.1038/nature07717, 2009.

Tinner, W., van Leeuwen, J. F. N., Colombaroli, D., Vescovi, E., van der Knaap, W. O., Henne, P. D., Pasta, S., D'Angelo, S., and La Mantia, T.: Holocene environmental and climatic changes at Gorgo Basso, a coastal lake in southern Sicily, Italy, Quaternary Sci. Rev., 28, 1498-1510, https://doi.org/10.1016/j.quascirev.2009.02.001, 2009.

Tintore, J., La Violette, P. E., Blade, I., and Cruzado, A.: A study of an intense density front in eastern Alboran Sea: the Almeria-Oran Front, J. Phys. Oceanogr., 18, 1384-1397, https://doi.org/10.1175/15200485(1988)018<1384:ASOAID>2.0.CO;2, 1988.

Toucanne, S., Jouet, G., Ducassou, E., Bassetti, M., Dennielou, B., Morelle, C., Minto, A., Lahmi, M., Touyet, N., Charlier, K., Lericolais, G., and Mulder, T.: A 130,000-year record of Levantine Intermediate Water flow variability in the Corsica Trough, western Mediterranean Sea, Quaternary Sci. Rev., 33, 55-73, https://doi.org/10.1016/j.quascirev.2011.11.020, 2012.

Trigo, R. M., Osborn, T. J., and Corte-Real, J. M.: The North Atlantic Oscillation influence on Europe: climate impacts and associated physical mechanisms, Clim. Res., 20, 9-17, https://doi.org/10.3354/cr020009, 2002.

Tzedakis, P. C.: Seven ambiguities in the Mediterranean palaeoenvironmental narrative, Quaternary Sci. Rev., 26, 2042-2066, https://doi.org/10.1016/j.quascirev.2007.03.014, 2007.

van Raden, U. J., Groeneveld, J., Raitzsch, M., and Kucera, M.: $\mathrm{Mg} / \mathrm{Ca}$ in the planktonic foraminifera Globorotalia inflata and Globigerinoides bulloides from Western Mediterranean plankton 
tow and core top samples, Mar. Micropaleontol., 78, 101-112, https://doi.org/10.1016/j.marmicro.2010.11.002, 2011.

Versteegh, G. J. M., de Leeuw, J. W., Taricco, C., and Romero, A.: Temperature and productivity influences on U37 K0 and their possible relation to solar forcing of the Mediterranean winter, Geochem. Geophy. Geosy., 8, 1-14, https://doi.org/10.1029/2006GC001543, 2007.

Volkman, J. K., Eglinton, G., Corner, E. D. S., and Sargent, J. R.: Novel unsaturated straight-chain $\mathrm{C}_{37}-\mathrm{C}_{39}$ methyl and ethyl ketones in marine sediment and a coccolithophore Emiliania huxleyi, Phys. Chem. Earth, 12, 219-227, doi.org/10.1016/00791946(79)90106-X, 1980.

Wanner, H., Beer, J., Bütikofer, J., Crowley, T. J., Cubasch, U., Flückiger, J., Goosse, H., Grosjean, M., Joos, F., Kaplan, J. O., Küttel, M., Müller, S. A., Prentice, I. C., Solomina, O., Stocker, T. F., Tarasov, P., Wagner, M., and Widmann, M.: Mid- to Late Holocene climate change: an overview, Quaternary Sci. Rev., 27, 1791-1828, https://doi.org/10.1016/j.quascirev.2008.06.013, 2008.
Zielhofer, C., Fletcher, W. J., Mischke, S., De Batist, M., Campbell, J. F. E., Joannin, S., Tjallingii, R., El Hamouti, N., Junginger, A., Stele, A., Bussmann, J., Schneider, B., Lauer, T., Spitzer, K., Strupler, M., Brachert, T., and Mikdad, A.: Atlantic forcing of Western Mediterranean winter rain minima during the last 12,000 years Christoph, Quaternary Sci. Rev., 157, 29-51, https://doi.org/10.1016/j.quascirev.2016.11.037, 2017. 